\title{
The Mechanisms of PD-L1 Regulation in Non-Small-Cell Lung Cancer (NSCLC): Which Are the Involved Players?
}

\author{
Giuseppe Lamberti ${ }^{1}$, Monia Sisi ${ }^{1}$, Elisa Andrini ${ }^{1}$, Arianna Palladini ${ }^{2}{ }^{4}$, Francesca Giunchi ${ }^{3}$, \\ Pier-Luigi Lollini ${ }^{2}{ }^{(-)}$, Andrea Ardizzoni ${ }^{1,4}$ and Francesco Gelsomino ${ }^{4, *}$ \\ 1 Department of Experimental, Diagnostic and Specialty Medicine, S. Orsola-Malpighi University Hospital, \\ Alma Mater Studiorum University of Bologna, Via Massarenti 9, 40138 Bologna, Italy; \\ giuseppe.lamberti8@unibo.it (G.L.); monia.sisi@studio.unibo.it (M.S.); elisa.andrini2@studio.unibo.it (E.A.); \\ andrea.ardizzoni@aosp.bo.it (A.A.) \\ 2 Laboratory of Immunology and Biology of Metastasis, Department of Experimental, Diagnostic and \\ Specialty Medicine (DIMES), University of Bologna, viale Filopanti 22, 40126 Bologna, Italy; \\ arianna.palladini@unibo.it (A.P.); pierluigi.lollini@unibo.it (P.-L.L.) \\ 3 Laboratory of Oncologic Molecular Pathology, S.Orsola-Malpighi Teaching Hospital, University of Bologna, \\ Via Massarenti 9, 40138 Bologna, Italy; francesca.giunchi@aosp.bo.it \\ 4 Oncologia Medica, Azienda Ospedaliero-Universitaria di Bologna, Via Albertoni-15, 40138 Bologna, Italy \\ * Correspondence: francesco_gelsomino@aosp.bo.it; Tel.: +39-0512142204
}

Received: 16 September 2020; Accepted: 21 October 2020; Published: 26 October 2020

check for updates

Simple Summary: Immunotherapy against PD-1/PD-L1 dramatically improved outcomes in non-small cell lung cancer patients. These treatments are more effective the higher the expression of PD-L1 on tumor cells, reported as tumor proportion score. However, PD-L1 expression can be highly variable, depending on different mechanisms of regulation. These mechanisms are usually grouped in intrisc (including genetic and epigenetic factors) and extrinsic factors (i.e., deriving from interaction of tumor cells with tumor microenvironment or other external factors). We reviewed mechanisms underlying PD-L1 expression regulation in order to provide a comprehensive overview and identify key regulatory factors that are or can potentially be exploited to improve outcomes on immune checkpoint inhibitors targeting the PD-1/PD-L1 axis.

\begin{abstract}
Treatment with inhibition of programmed cell death 1 (PD-1) or its ligand (PD-L1) improves survival in advanced non-small-cell lung cancer (NSCLC). Nevertheless, only a subset of patients benefit from treatment and biomarkers of response to immunotherapy are lacking. Expression of PD-L1 on tumor cells is the primary clinically-available predictive factor of response to immune checkpoint inhibitors, and its relevance in cancer immunotherapy has fostered several studies to better characterize the mechanisms that regulate PD-L1 expression. However, the factors associated with PD-L1 expression are still not well understood. Genomic alterations that activate KRAS, EGFR, and ALK, as well as the loss of PTEN, have been associated with increased PD-L1 expression. In addition, PD-L1 expression is reported to be increased by amplification of CD274, and decreased by STK11 deficiency. Furthermore, PD-L1 expression can be modulated by either tumor extrinsic or intrinsic factors. Among extrinsic factors, the most prominent one is interferon- $\gamma$ release by immune cells, while there are several tumor intrinsic factors such as activation of the mechanistic target of rapamycin (mTOR), mitogen-activated protein kinase (MAPK) and Myc pathways that can increase PD-L1 expression. A deeper understanding of PD-L1 expression regulation is crucial for improving strategies that exploit inhibition of this immune checkpoint in the clinic, especially in NSCLC where it is central in the therapeutic algorithm. We reviewed current preclinical and clinical data about PD-L1 expression regulation in NSCLC.
\end{abstract}


Keywords: PD-L1; PD-1; non-small-cell lung cancer; immunotherapy; immune checkpoint inhibitors; T-cell

\section{Introduction}

Programmed death-1 (PD-1) is a type I transmembrane protein expressed on the surface of antigen-stimulated $\mathrm{T}$ cells on which it exerts an inhibitory effect when binding with its ligand programmed-death ligand 1 (PD-L1), which can be expressed by normal cells, immune cells and tumor cells [1]. PD-1 and PD-L1 are referred to as immune checkpoints since they modulate the adaptive immune response to avoid an exaggerated activation and thus play a key role in immune homeostasis. Given its crucial role, PD-L1 expression on the cell membrane is finely regulated at different levels. These involve multiple factors that are classified as intrinsic (i.e., originating within the cell) and extrinsic (i.e., determined by factors outside of the cell), which modulate constitutive and inducible PD-L1 expression, respectively.

However, PD-L1 can be aberrantly expressed on tumor cells, allowing them to escape immune surveillance and consequent killing by the host adaptive immune system. Targeting PD-1 or PD-L1 with specific immune checkpoint inhibitors (ICIs) to prevent their interaction yielded dramatic results and improved outcomes in several hard-to-treat cancers, including melanoma, urothelial carcinoma, small-cell and non-small-cell lung cancer (NSCLC) [2-13]. In NSCLC, PD-L1 expression reported as the percentage of viable tumor cells showing membranous staining for PD-L1 at immunohistochemistry (tumor proportion score, TPS) is a predictive biomarker of response to ICIs targeting PD-1 or PD-L1. Furthermore, higher PD-L1 expression levels in NSCLC are associated with improved outcomes on ICI targeting PD-1 [4,14,15]. Nevertheless, PD-L1 expression on tumor cells is highly variable and different expression levels are associated with different clinicopathological and genomic characteristics in NSCLC [16]. Understanding the mechanisms that underlie PD-L1 expression in the oncology perspective will help in developing novel strategies to improve outcomes on ICIs, by either delaying or overcoming the onset of resistance to this class of drugs through increasing or re-enabling PD-L1 expression on tumor cells or preventing PD-L1 downregulation.

In this review, we will summarize the molecular factors that affect PD-L1 expression in NSCLC and discuss their potential translational clinical applications.

\section{Intrinsic Factors}

Genetic and epigenetic alterations that affect constitutive PD-L1 expression on tumor cells are referred to as intrinsic factors (Figure 1).

\subsection{Genetic Factors}

\subsubsection{RAS and Mitogen-Activated Protein Kinase}

Kirsten Ras Sarcoma Viral Oncogene Homolog $(K R A S)$ harbors activating mutations in about a third of lung adenocarcinomas [17]. Activated RAS induces mitogen-activated protein kinase (MAPK) activation, which in turn inhibits tristetraprolin (an adenylate-uridylate-rich element-binding protein) by p38-dependent phosphorylation. Furthermore, activated RAS stabilizes PD-L1 mRNA. Both mRNA stabilization and tristetraprolin inhibition result in increased PD-L1 expression in lung cancer cell lines [18,19]. This is consistent with the decrease in PD-L1 expression in both mouse and human KRAS-mutant lung cancer cells observed with concomitant Mitogen-activated ERK kinase (MEK) and extracellular signal-regulated kinase (ERK) inhibition [18-20]. On the other side, MEK inhibition alone (i.e., without concomitant ERK inhibition) leads to increased PD-L1 expression, possibly because of feedback mechanisms that induce paradoxical activation of the MAPK pathway [21]. 


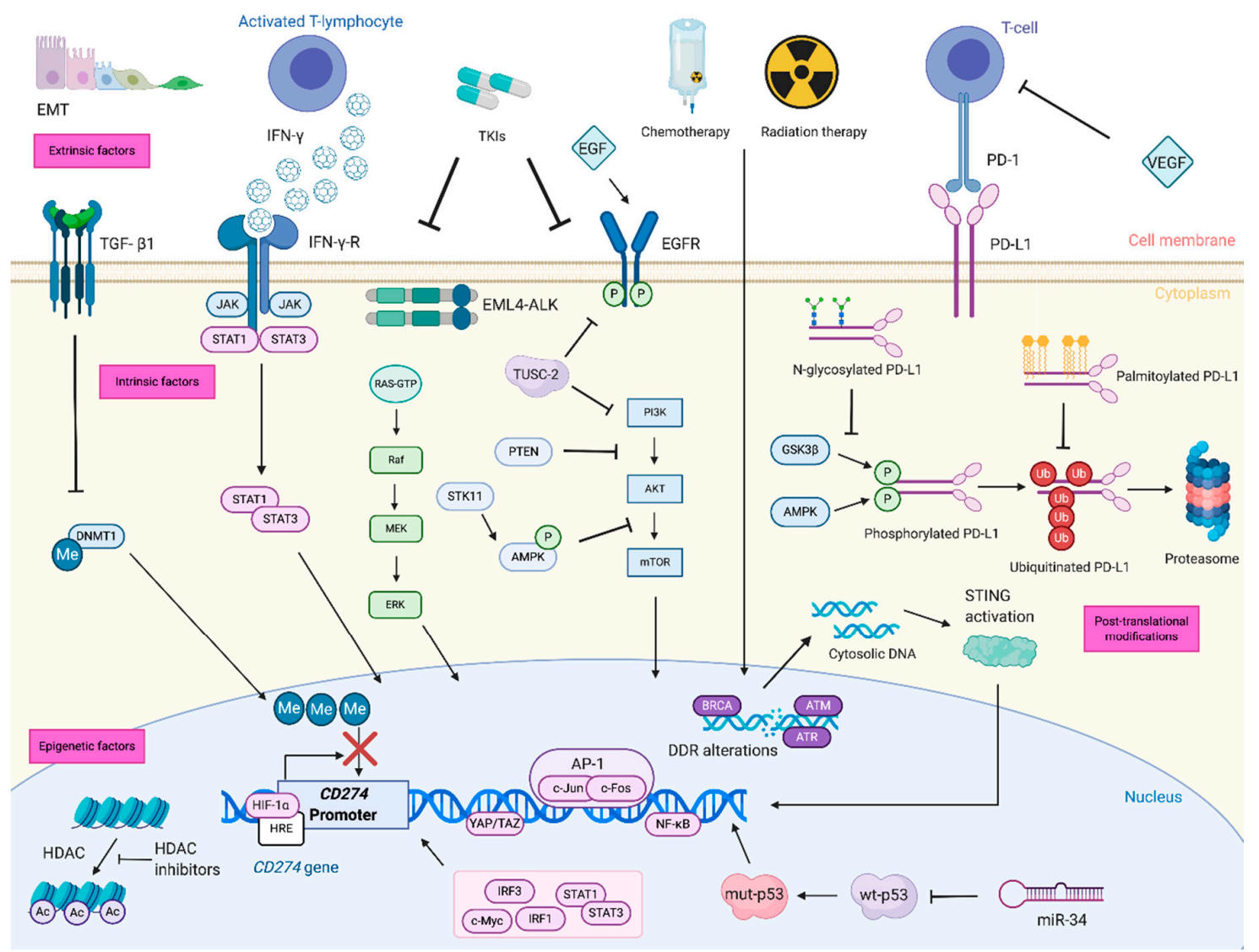

Figure 1. Regulation of PD-L1 expression involved several factors at different levels. The main extrinsic factors involved in PD-L1 regulation are pictured on the top of the picture and include cytokines (e.g., IFN- $\gamma$ ), growth factors (e.g., EGF), hypoxia, chemotherapy, radiation therapy and TKIs, which regulate PD-L1 expression on the transcriptional level. Among intrinsic factors, genetic alterations, involve intracellular signaling pathways (e.g., MAPK, PI3K/Akt/mTOR, JAK/STAT), tumor suppressor genes (e.g., TP53, STK11), DDR genes (e.g., BRCA1-2, ATM, ATR) and transcription factors (e.g., c-Myc, NF-kB). Other intrinsic factors include epigenetic modifications: CD274 promoter methylation, inhibition of histone deacetylase and regulation of gene translation by miRNAs. The main post-translational modifications able to regulate PD-L1 stability and expression are phosphorylation, ubiquitination, glycosylation and palmitoylation (pictured on the right-hand side). Created with BioRender.com. EGF: Epidermal Growth Factor; EGFR: Epidermal Growth Factor receptor; EML4-ALK: echinoderm microtubule-associated protein-like 4 gene-anaplastic lymphoma kinase gene; IFN- $\gamma$ : interferon-gamma; IFN- $\gamma$ R: interferon-gamma receptor; TGF- $\beta 1$ : tumor growth factor beta 1 ; TKIs: tyrosine kinase inhibitors; VEGF: vascular endothelial growth factor; PD-1: programmed-cell death; PD-L1: programmed-cell death ligand 1; TUSC2: tumor suppressor candidate 2; PI3K: phosphatidylinositol 3-kinase; Akt: Protein kinase B; mTOR: mammalian target of rapamycin; JAK: Janus kinase; STAT: signal transducer and activator of transcription; NF-KB: nuclear factor kappa-light-chain-enhancer of activated B cells; TP53: Tumor protein p53; STK11: Serine/threonine kinase 11; DDR: DNA damage response and repair; BRCA1-2: breast cancer type 1 and 2 susceptibility proteins; ATM: Ataxia Telangiectasia Mutated; ATR: ATM related protein; RAS: Rat Sarcoma Viral Oncogene Homolog; MEK: Mitogen-activated ERK kinase; ERK: Extracellular signal-Regulated Kinases; AMPK: 5' AMP-activated protein kinase; PTEN: Phosphatase and tensin homolog; AP1: Activator protein 1; DNMT1: DNA methyl-transferase 1; IRF: interferon regulatory factor; Me: methyl group, P: phosphate group, STING: stimulator of interferon genes; HIF-1 $\alpha$ : Hypoxia-inducible factor 1-alpha, HRE: hypoxia-response element, HDAC: Histone deacetylase; HDACi: Histone deacetylase inhibitors; EMT: epithelial-mesenchymal transition; GSK3 $\beta$ : glycogen synthase kinase 3beta. 


\subsubsection{Receptor Tyrosine Kinases}

Upstream of KRAS, the epidermal growth factor receptor (EGFR) activation by its ligand binding (EGF) induces PD-L1 expression on NSCLC cells through the phosphatidylinositol 3-kinase-Protein kinase B-mammalian target of rapamycin (PI3K/Akt/mTOR) and the Janus kinase-signal transducer and activator of transcription (JAK/STAT) pathways [22]. EGFR is mutated in about $10-25 \%$ of lung adenocarcinomas and is associated with female sex, absence of smoking history and Asian ethnicity [23-25]. In EGFR-mutant NSCLC, EGFR can increase PD-L1 expression through activation of several pathways, including MAPK [26,27], PI3K/Akt/mTOR [27,28], and JAK2/STAT1 and STAT3 in the JAK/STAT pathway $[29,30]$. Despite the association with a high PD-L1 expression in a small cohort of resected NSCLC specimens [31], the presence of activating EGFR mutations is associated with low expression of PD-L1 on tumor cells, as well as a poor outcome to ICIs [16,32-34]. Nonetheless, this effect might be depending on the type of EGFR activating mutation $[35,36]$. This apparent paradox can be explained by the complex interaction between tumor cells and the tumor microenvironment (TME). In fact, EGFR-mutant cancer cells tend to have a lower tumor mutational burden (TMB), defined as the total number of nonsynonymous mutations per coding area of a tumor genome (Mut/Mb) [37], and to be less immunogenic compared to EGFR wild-type tumors. In this context, the deficient interaction between EGFR-mutant tumor cells and host immune system cells leads to low T-cell infiltrate which may impair PD-L1 inducible expression [38-40].

Similarly, the presence of an anaplastic lymphoma kinase $(A L K)$ rearrangement in NSCLC is associated with high PD-L1 expression via activation of the MEK/ERK, PI3K/Akt/mTOR pathways and STAT3 [41-43]. The latter can increase PD-L1 transcription by directly binding the promoter region of the CD274 gene (located on chromosome 9 in the 9p24.1 locus and encoding PD-L1) [43].

\subsubsection{PI3K/Akt/mTOR}

The PI3K/Akt/mTOR pathway is central in cell homeostasis maintenance and metabolism regulation and is altered in several cancer types, including NSCLC [44,45]. In this tumor type, PD-L1 expression is increased by PI3K/Akt/mTOR activation mediated by either Phosphatase and tensin homolog (PTEN) inactivation or loss, or mTOR activation [28,46,47]. Activated mTOR acts at the post-transcriptional level by recruiting PD-L1 transcripts to active polysomes so that the PD-L1 protein level is increased without a corresponding significant elevation in mRNA levels [20]. Accordingly, tumor suppressor candidate 2 (TUSC2) overexpression determines reduced PD-L1 expression by impairing effect of EGFR, mTOR and Akt activation on PD-L1 expression [48,49].

\subsubsection{Tumor Suppressors}

Recently, the role of tumor suppressors in tuning PD-L1 expression in NSCLC has been widely explored and has gained attention thanks to implications with outcomes to ICIs. Preserved p53 function reduces PD-L1 expression via miR-34 [50]. On the contrary, deleterious mutations of TP53, which encodes p53, or aberrant p53 expression, which reflects protein loss of function, are associated with increased PD-L1 expression [51,52] and immune infiltrate, resulting in improved outcome to ICIs [51]. These effects were amplified in NSCLC with co-occurring TP53 and KRAS mutations. A similar association between high PD-L1 expression and p53 overexpression was observed in resected primary lymphoepithelioma-like carcinoma of the lung, a rare type of NSCLC [53].

Serine/threonine kinase 11 (STK11, or liver kinase B1, LKB1) is a tumor suppressor that is often found mutated in lung adenocarcinoma, especially in presence of co-occurring KRAS mutations. Mutation or loss of STK11 is associated with low or absent PD-L1 expression, in both KRAS-mutant and $K R A S$-wild type lung adenocarcinoma, and with impaired efficacy of ICIs targeting the PD-1/PD-L1 axis [16,54]. This can be explained by the fact that STK11 deletion in KRAS-driven lung adenocarcinoma promotes the accumulation of neutrophils with T-cell suppressive function, as observed in mouse models [55]. Moreover, an immune "cold" TME can be responsible for the absent or low PD-L1 
expression associated with STK11 mutation or loss in NSCLC [55]. Concurrent PTEN and STK11 loss favors, in vivo, the growth of squamous NSCLC with high PD-L1 expression [56], while lung tumors with adenocarcinoma histology and high PD-L1 expression can be observed in mice where PTEN is simultaneously lost with Kelch-like ECH-associated protein 1 (KEAP1), rather than STK11 [57].

DNA damage response and repair (DDR) genes are a large family of genes that encode for caretaker tumor suppressors proteins, such as breast cancer type 1 and 2 susceptibility proteins (BRCA1 and BRCA2), ataxia telangiectasia Mutated (ATM), ATM-related protein (ATR) and many others [58]. Alterations in DDR genes determine the accumulation of cytosolic DNA that induces PD-L1 expression in response to activation of the stimulator of interferon genes (STING) [58]. DDR mutations have been associated with increased TMB and improved outcomes to ICIs in NSCLC patients so that combination strategies of DDR inhibitors and ICI are under evaluation in these patients [59,60]. PD-L1 expression is increased in response to STING activation thanks to type I interferon response 3 (IRF3) directly binding to CD274 promoter [58]. Interferon-gamma produced by activated $\mathrm{T}$ cells binds to its receptor on tumor cells and determines STAT1 activation and transcription of IRF1/7 which in turn binds to the CD274 promoter, increases PD-L1 transcription and, ultimately, the expression on tumor cells [61].

The CD274 promoter is the target of several transcription factors since a fine-tuning of PD-L1 expression on tumor cells is needed. Casey et al. showed that Myc can directly bind the CD274 promoter in several cancer cell lines, including NSCLC cell line H1299 [62]. Consistently, an inverse correlation has been observed between PD-L1 and bridging integrator-1 (BIN1) expression, since the latter inhibits Myc- and EGFR-MAPK-mediated induction of PD-L1 expression [63]. Furthermore, several other transcription factors regulate PD-L1 expression by directly binding the CD274 promoter or other regulating regions. PD-L1 expression is regulated by NF- $\mathrm{BB}$ through the RELA/p65-MUC1-C complex [64], as well as by c-Jun and the activator protein-1 (AP-1), which binds the first intron of CD274, in a STAT3-dependent way in KRAS-mutant NSCLC [20]. Yes-associated protein 1 (YAP) and WW domain-containing transcription regulator 1 (TAZ) are key components of the Hippo pathway which is commonly deregulated in lung cancer and whose activation determines the upregulation of PD-L1 expression $[65,66]$. The positive correlation of expression of YAP and PD-L1 determined by immunohistochemistry in human NSCLC cells corroborates this [67]. The transcriptional enhancer factor 1 (TEF-1) is a downstream effector of the Hippo pathway and also directly binds the CD274 promoter enhancing PD-L1 expression in lung cancer cell lines [66-69]. As a consequence, upstream kinases and inhibitors of the Hippo pathway, mammalian STE20-like kinase 1 and 2 (MLST1/2) and large tumor suppressor 1 and 2 (LATS1/2), have been shown to decrease PD-L1 expression [66].

Amplification of CD274 has been reported in up to $6 \%$ of nonsquamous NSCLC [16,70-72] and to be associated with high PD-L1 expression [16,71] as well as increased TMB [16,73]. These associations are remarkable as they might also predict susceptibility to anti-PD-1 treatment [74].

The integrity of $3^{\prime}$-UTR is critical for the regulation of CD274 mRNA transcription and PD-L1 expression. In fact, disruption of $3^{\prime}$-UTR determines immune escape through increased PD-L1 expression in several cancer cell lines, including PC-9 lung adenocarcinoma cell lines [75].

\subsection{Epigenetic Factors}

DNA methylation and histone acetylation are epigenetic modifications that modulate gene expression in normal as well as a tumor cell. Aberrant epigenetic changes play a key role in cancer progression and development and can also affect PD-L1 expression [76].

\subsubsection{Methylation}

Methylation of the CD274 promoter downregulates PD-L1 transcription, and is reported to be implicated in resistance to anti-PD-L1 ICIs in NSCLC resistant to EGFR inhibition [77,78]. In lung cancer cells undergoing epithelial-mesenchymal transition (EMT), tumor growth factor-beta 1 (TGF- $\beta 1$ ) decreases expression of the DNA methyl-transferase 1 (DNMT1), an enzyme that methylates the CD274 promoter, thus resulting in increased PD-L1 expression [77]. Similarly, the addition of NSCLC 
cell lines of azacytidine, a general inhibitor of methylation, increases CD274 transcription and PD-L1 expression [79]. Decitabine, an azacytidine-related hypomethylating agent, can also synergistically improve the activity of anti-PD-L1 ICIs in lung cancer cells, compared to either agent alone [80].

\subsubsection{Histone Modifications}

In NSCLC, histone deacetylase (HDAC) 10 expression is positively correlated with PD-L1 expression and is independently associated with poor outcome [81]. Histone deacetylase inhibitors (HDACis) have been recently investigated as therapeutic agents in several cancer types and have been shown to require an intact immune system to exert their anticancer action [82]. HDACis increase PD-L1 expression and immune infiltrate in NSCLC models and have been shown to synergize with anti-PD-1 blockade in NSCLC models $[83,84]$.

\subsubsection{Micro RNAs}

MicroRNAs (miRNAs) are small non-coding RNAs that regulate target genes by inhibition of their translation after transcription, whose deregulation is associated with cancer genesis and progression [85]. Depending on the targeted mRNA, miRNAs can have different effects on PD-L1 expression. In NSCLC cell lines, miR-135 which targets tripartite-motif (TRIM) 16, and miR-3127-5p which positively regulates STAT3, are associated with increased PD-L1 expression [86,87]. On the other hand, miR-197 inhibits Cyclin-dependent kinases regulatory subunit 1 (CKS1B) by decreasing STAT3 activation thus reducing PD-L1 expression on NSCLC cells [88]. Similarly, miR-142-5p reduces PD-L1 expression through PTEN inhibition on lung adenocarcinoma cells [89]. CD274 transcript can also be directly targeted through binding the 3'-UTR by miRNAs, such as miR-140, miR-200c, and miR-34, resulting in decreased CD274 translation and, eventually, PD-L1 expression [50,90,91]. In addition, a signature of seven miRNAs found in the serum of NSCLC patients (215-5p, 411-3p, 493-5p, 494-3p, 495-3p, 548j-5p and 93-3p) has been associated with overall survival to nivolumab [92].

\section{Extrinsic Factors}

Inducible expression of PD-L1 is mediated by extrinsic factors such as inflammatory signals, cytokines, growth factors, hypoxia, radiation therapy, chemotherapy and targeted therapies [43,93-99].

\subsection{Cytokines}

Chronic inflammation promotes the release of pro-inflammatory cytokines, such as Interferon-gamma (IFN- $\gamma$ ) and alfa (IFN- $\alpha$ ), tumor necrosis factor-alfa (TNF- $\alpha$ ), Interleukin (IL)-1a and IL-27, which induce PD-L1 expression in the TME [61,100-102]. IFN- $\gamma$ released by tumor-infiltrating lymphocytes (TILs) is the most important cytokine in inducing PD-L1 expression on tumor cells, promoting tumor immune escape $[103,104]$. The IFN- $\gamma$-mediated PD-L1 upregulation occurs mainly through JAK/STAT/IRF1 signaling pathway activation in several types of cancers, including NSCLC, resulting in binding of IRF1 to the CD274 promoter $[61,100,105,106]$. Similarly, TNF- $\alpha$, IL-1a and IL-27 can induce PD-L1 expression, acting synergistically with IFN- $\gamma[103,107]$. On the contrary, IL-10 inhibits expression of IFN- $\gamma$ targeted genes, including PD-L1 [108].

\subsection{Growth Factors}

The interaction between tumor cells and TME can modulate the effect that intrinsic factors exert on PD-L1 expression. For example, as already mentioned, EGFR activation by EGF binding can induce PD-L1 expression on tumor cells; however, EGFR-mutant NSCLCs tend to have lower PD-L1 expression levels compared to $E G F R$-wild type tumors as a result of the interaction between tumor cells and the immune TME [38-40].

TGF- $\beta$ is a key inductor of EMT which is characterized by increased tumor proliferation, invasion, metastasis and immune surveillance escape ability $[77,109,110]$. It was demonstrated that 
TGF- $\beta 1$-induced EMT leads to increased PD-L1 expression in NSCLC cell lines through both the demethylation of PD-L1 gene promoter and the activation of the NF- $K B$ signaling pathway [109]. Based on this data, a combination of PD-L1 blockade and TGF- $\beta$ inhibition represents an intriguing therapeutic strategy to overcome tumor immune escape and resistance, as discussed below. In cancer stem cells, and to a lesser extent in normal cancer cells, EMT-associated $\beta$-catenin activation induces expression of $\mathrm{N}$-glycosyltransferase STT3 that stabilized and thus upregulates PD-L1 through N-glycosylation [111].

\subsection{DNA Damaging Agents}

Radiation therapy and chemotherapy can induce PD-L1 expression thanks to their ability to generate DNA damage [94]. Specifically, radiation therapy and chemotherapy induce DNA double-strand breaks as the main type of DNA damage whose repair is associated with PD-L1 upregulation in cancer cells through the activation of ATM/ATR/Checkpoint kinase 1 (Chk1) and STAT1/3-IRF1 pathway [94]. Recently in vitro study showed that treatment with pemetrexed enhanced PD-L1 expression, both in its membrane-bound form and its soluble form, in non-squamous NSCLC cell lines through activation of mTOR and STAT3 signaling pathways, whereas other chemotherapeutic agents (e.g., gemcitabine, paclitaxel, vinorelbine, cisplatin) did not influence PD-L1 levels [112]. In addition, pemetrexed led to increased release of pro-inflammatory cytokines (e.g., IFN- $\gamma$ and IL-2), that further stimulated PD-L1 expression on tumor cells, resulting in an immune favorable TME for anti-PD-1/PD-L1 therapy. These results could explain the significant clinical benefit obtained with platinum-pemetrexed and pembrolizumab combination as upfront treatment also in the subgroup of metastatic NSCLC patients with PD-L1 negative tumors [5].

\subsection{Targeted Therapies}

Additionally, targeted therapies can affect PD-L1 expression levels in NSCLC. As above mentioned, EGFR mutations are commonly associated with PD-L1 upregulation in NSCLC. Inhibition of EGFR signaling by EGFR tyrosine kinase inhibitors (TKIs), such as gefitinib and osimertinib, decreased PD-L1 expression through both down-regulation of PD-L1 mRNA and increased PD-L1 proteasomal degradation $[29,96,113]$. This can potentially lead to enhanced antitumor immunity, although not all studies were concordant since treatment with TKIs led to PD-L1 upregulation, resulting in immune suppression according to some reports [114]. It was so hypothesized that TKIs could have a dual-phase regulation, with PD-L1 downregulation in an early phase, corresponding to the initial potent antitumor activity of these drugs, followed by a later phase, corresponding to the onset of TKI resistance, in which PD-L1 expression is increased [114,115]. Hence, monitoring changes in PD-L1 expression levels during EGFR TKI treatment could help predict the development of resistance [114].

\subsection{Angiogenesis and Hypoxia}

Cancer cells also produce proangiogenic factors that induce aberrant angiogenesis within tumors that is a crucial process for tumor growth and survival. The vascular endothelial growth factor (VEGF) is the most important proangiogenic factor, which also has pleiotropic effects on antitumor immune response since it inhibits antigen presentation, promotes regulatory T-cell infiltration and induces PD-L1 expression on tumor-infiltrated T-cells [116].

Tumoral aberrant angiogenesis caused abnormal vasculature which eventually generates hypoxia, a hallmark of TME. Cancer cells survive in hypoxic conditions through the activation of hypoxia-inducible factors (HIFs) [117]. Among HIFs, HIF- $1 \alpha$ is a major oncogenic factor that facilitates the adaptation of cancer cells to stress, allowing their survival. HIF- $1 \alpha$ directly binds the hypoxia-response element (HRE) in the CD274 proximal promoter, inducing PD-L1 expression in myeloid-derived suppressor cells (MDSCs) and tumor cells [43,118]. Interestingly, lactates produced in hypoxic TME interact with their receptor GPR81 and induce PD-L1 expression through the activation of TAZ, which is a major downstream effector of the Hippo Pathway [69]. Consequently, hypoxia 
leads to increased HIF- $1 \alpha$ levels resulting in T-cell suppression and an overall immunosuppressive TME $[43,118,119]$.

\section{Post-Translational Modification}

PD-L1 expression and stability are finely tuned by several post-translational modifications, such as phosphorylation, glycosylation and ubiquitination [120,121].

\subsection{Phosphorylation}

The serine/threonine kinases glycogen synthase kinase 3beta (GSK3 $\beta$ ) and AMP-activated protein kinase (AMPK) phosphorylate PD-L1 at the Thr180 and Ser184 residues, respectively, located in two specific and evolutionarily conserved phosphorylation motifs [122,123]. PD-L1 phosphorylation leads to increased PD-L1 E3 ligase mediated-proteasomal degradation, when PD-L1 is phosphorylated by GSK3 $\beta$, while it leads to endoplasmic reticulum-associated degradation, when PD-L1 is phosphorylated by AMPK. Furthermore, EGF-mediated GSK3 $\beta$ inactivation prevents PD-L1 phosphorylation and poly-ubiquitination, stabilizing the protein and increasing its expression $[117,122,124]$.

\subsection{Glycosylation}

Glycosylation is a crucial post-translational modification that alters protein conformation and stability, regulating their activities and interactions [124]. PD-L1 is highly glycosylated in human tumor tissues and in cancer cell lines [122]. Glycosylation of PD-L1 is completely inhibited by the N-linked glycosylation inhibitor tunicamycin, whereas it is not affected by O-glycosidase treatment, suggesting that N-glycosylation is the main type of PD-L1 glycosylation [122]. Furthermore, N-glycosylation occurs exclusively at evolutionarily conserved motifs (N35, N192, N200 and N219) in PD-L1 extracellular domain. N-glycosylation of N192, N200 and N219, but not N35, on PD-L1 protein, antagonizes the interaction between PD-L1 and GSK3 $\beta$ through steric hindrance and, consequently, prevents GSK3 $\beta$-mediated phosphorylation of PD-L1 $[117,124]$. The resulting prevention of its ubiquitination and degradation by the $26 \mathrm{~S}$ proteasome, stabilizes PD-L1 protein, supporting a key role of PD-L1 glycosylation in promoting tumor immune evasion [122,125]. Interestingly, the majority of PD-L1 in tumor cells is glycosylated, so that it cannot be degraded by the proteasome [121,122], and is masked to diagnostic immunohistochemistry assays [126].

\subsection{Ubiquitination}

Ubiquitination is an important post-translational modification, leading to proteasomal degradation of target proteins, including PD-L1 [127]. Ubiquitination is a key regulator of PD-L1 stability, through a balance between mono- and multi-ubiquitination on one side, and poly-ubiquitination on the other side [120]. Specifically, the attachment of ubiquitin to proteins as a monomer on one or more lysine residues is referred to as monoubiquitination or multiubiquitination, respectively, whereas its conjugation as a polymer, through sequential cycles of ubiquitination, leads to polyubiquitination [128]. Poly-ubiquitination of non-glycosylated PD-L1 leads to protein degradation and, consequently, to PD-L1 downregulation, whereas it was reported that PD-L1 mono- and multi-ubiquitination, e.g., in response to EGF stimulation, leads to increased PD-L1 protein expression [120].

\subsection{Palmitoylation}

Palmitoylation (also known as thioacylation or S-acylation) is the main type of protein lipidation, consisting of the addition of palmitate to a cysteine residue, generally with a reversible thioester linkage [129]. Palmitoylation plays a crucial role in the regulation of trafficking and function of several proteins including RAS and EGFR, but also in the regulation of PD-L1 stability. In fact, palmitoylation of PD-L1, mainly catalyzed by palmitoyltransferase ZDHHC3 (DHHC3), leads to suppression of PD-L1 ubiquitination and degradation, resulting in protein stabilization, eventually promoting tumor immune 
escape [130]. Based on this data, targeting this post-translational modification, e.g., by silencing DHHC3, could represent a promising therapeutic strategy to promote PD-L1 degradation and activate antitumor immunity.

\section{Potential Clinical Applications}

The increasing understanding of the molecular mechanisms underlying PD-L1 expression regulation unravels potential therapeutic approaches to improve immunotherapy efficacy.

\subsection{Targeting the PI3K/AKT/mTOR Pathway}

The PI3K/AKT/mTOR pathway is a key regulator of PD-L1 expression in NSCLC since it mediates both constitutive and inducible expression resulting from either alteration of oncogenes (e.g., EGFR, $K R A S$, and $A L K)$ or extrinsic factors (e.g., IFN- $\gamma$ or EGF), respectively.

Suppression of PI3K $\gamma$-mTOR signal by PI3K $\gamma$ inhibition enhances tumor regression and prolongs survival in a synergistic fashion with PD-1 blockade in mouse models of cancer [47]. Buparlisib (BKM120) is an oral pan-PI3K inhibitor that was evaluated in phase II BASALT-1 trial in 63 pre-treated patients with recurrent NSCLC harboring documented aberrations in the PI3K pathway [131]. However, the study stopped early for futility because it did not meet its efficacy criterion (12-week PFS $\geq 50 \%$ ) [131].

PI3K/Akt/mTOR pathway inhibition after progression on PD-1/PD-L1 blockade may overcome acquired resistance to ICIs secondary to PI3K/Akt/mTOR upregulation. To test this hypothesis, a phase study II trial of Ipatasertib, a novel highly selective ATP-competitive pan-Akt inhibitor, in combination with docetaxel in advanced NSCLC patients progressed to first-line immunotherapy is currently ongoing (NCT04467801). Trials of combination therapies of PI3K/Akt/mTOR inhibitors with immune checkpoint inhibitors are currently ongoing (Table 1).

\subsection{Targeting DNA Damage Response}

Among DDR proteins, poly (ADP-ribose) polymerase (PARP) is a family of protein which has been successfully targeted in breast, ovarian, prostate, and pancreatic cancers [132-137]. PARP inhibitors (PARPis), such as olaparib, talazoparib, rucaparib and niraparib, synergistically enhance PD-L1 blockade efficacy both in vitro and in vivo models [138-141] and are thus being evaluated in combination with ICIs in different cancer types [142-144]. No definitive data is currently available about combination treatments in NSCLC patients, but several trials are ongoing (Table 1).

\subsection{Epigenetic Agents}

Novel strategies involving drugs targeting epigenetic modifications as single-agent or in combination with other treatments have been developed in preclinical models and are moving to the clinical setting in NSCLC [145]. Combinations of epigenetic drugs and immunotherapies are currently being evaluated in multiple trials enrolling lung cancer patients. The ENCORE 601 study is a phase $\mathrm{Ib} / \mathrm{II}$ trial of entinostat, an orally available class I selective HDACi, in combination with pembrolizumab in NSCLC, melanoma and mismatch-repair proficient colorectal cancer patients (NCT02437136) [146]. The NSCLC cohort included both anti-PD-1/PD-L1 naïve and pre-treated patients and enrolled 22 patients. In these patients, the most commonly reported grade 3/4 treatment-related adverse events were hypophosphatemia $(9 \%)$, neutropenia (5\%), anemia (5\%), acute respiratory failure $(5 \%)$, elevated alkaline phosphatase $(5 \%)$ and immune-mediated hepatitis (5\%). However, the combination showed a modest activity profile: the best response was stable disease in $3 / 6$ pretreated patients, while one partial response, one stable disease and 9 progressive diseases were reported in PD-(L)1-naïve patients. 
Table 1. Ongoing clinical trials of therapies targeting PD-L1 expression regulation, in combination with immune checkpoint inhibitors (ICIs) in non-small-cell lung cancer (NSCLC): (source: www.clinicaltrials.gov, last accessed: 9 September 2020).

\begin{tabular}{|c|c|c|c|c|c|c|c|}
\hline NCT & Phase & $\begin{array}{l}\text { Experimental } \\
\text { Agent }\end{array}$ & Tumor & Setting & $N$ & Arm(s) & $\begin{array}{l}\text { Primary } \\
\text { Outcome(s) }\end{array}$ \\
\hline \multicolumn{8}{|c|}{ PI3K Inhibitor } \\
\hline NCT02637531 & I & IPI-549 & AST & After standard & 219 & IPI-549 \pm Nivolumab & $\begin{array}{l}\text { AEs } \\
\text { DLT }\end{array}$ \\
\hline NCT03257722 & $\mathrm{Ib} / \mathrm{II}$ & Idelalisib & NSCLC & Progressed on chemotherapy and ICIs & 40 & Idelalisib + Pembrolizumab & DLT \\
\hline NCT04282018 & $\mathrm{I} / \mathrm{II}$ & BGB-10188 & AST & $\begin{array}{l}\text { After standard } \\
\text { mTOR Inhibitor }\end{array}$ & 150 & BGB-10188 + Tislelizumab & AEs \\
\hline NCT04348292 & I & Sirolimus & Stage I-IIIA NSCLC & Neoadjuvant & 31 & Sirolimus + Durvalumab & $\begin{array}{l}\text { AEs } \\
\text { CPRR }\end{array}$ \\
\hline NCT03190174 & $\mathrm{I} / \mathrm{II}$ & $\begin{array}{c}\text { ABI-009 } \\
\text { (Nab-rapamycin) }\end{array}$ & AST & Any line & 40 & ABI-009 + Nivolumab & MTD \\
\hline \multicolumn{8}{|c|}{ JAK1 Inhibitor } \\
\hline NCT03425006 & II & Itactinib & NSCLC & 1st line & 48 & Itactinib + Pembrolizumab & $\begin{array}{l}\text { ORR } \\
\text { AEs }\end{array}$ \\
\hline \multicolumn{8}{|c|}{ PARP Inhibitor } \\
\hline NCT03330405 & $\mathrm{Ib} / \mathrm{II}$ & Talazoparib & AST & $B R C A$ or $A T M$ deficient & 214 & Talazoparib + Avelumab & $\begin{array}{l}\text { DLT } \\
\text { ORR }\end{array}$ \\
\hline NCT03559049 & $\mathrm{I} / \mathrm{II}$ & Rucaparib & NSCLC & $\begin{array}{l}\text { Maintenance after 1st line } \\
\text { immuno-chemotherapy }\end{array}$ & 55 & Pembrolizumab + Rucaparib & PFS \\
\hline NCT04538378 & II & Olaparib & $\begin{array}{l}\text { EGFR-mutated } \\
\text { NSCLC transformed } \\
\text { to SCLC }\end{array}$ & $\begin{array}{l}\text { After platinum-based chemotherapy } \pm \\
\text { immunotherapy for SCLC } \\
\text { trasformation }\end{array}$ & 14 & Olaparib + Durvalumab & BOR \\
\hline NCT03775486 & II & Olaparib & NSCLC & $\begin{array}{l}\text { Maintenance after 1st line } \\
\text { chemotherapy }\end{array}$ & 401 & Olaparib \pm Durvalumab & PFS \\
\hline NCT03308942 & II & Niraparib & NSCLC & 1st line & 53 & $\begin{array}{c}\text { Niraparib } \pm \\
\text { Pembrolizumab/Dostarlimab }\end{array}$ & ORR \\
\hline NCT04380636 & III & Olaparib & Stage III NSCLC & Unresectable & 870 & $\begin{array}{l}\text { Pembrolizumab }+ \text { chemoradiation } \rightarrow \\
\text { Pembrolizumab } \pm \\
\text { OlaparibChemoradiation } \rightarrow \text { Durvalumab }\end{array}$ & $\begin{array}{l}\text { PFS } \\
\text { OS }\end{array}$ \\
\hline NCT03976323 & III & Olaparib & NSCLC & $\begin{array}{l}\text { Maintenance after 1st line } \\
\text { immuno-chemotherapy }\end{array}$ & 792 & $\begin{array}{l}\text { Pembrolizumab + Olaparib } \\
\text { Pembrolizumab + Pemetrexed }\end{array}$ & $\begin{array}{l}\text { PFS } \\
\text { OS }\end{array}$ \\
\hline NCT03976362 & III & Olaparib & NSCLC & $\begin{array}{l}\text { Maintenance after 1st line } \\
\text { immuno-chemotherapy } \\
\text { (CBDCA + taxane) }\end{array}$ & 735 & Pembrolizumab \pm Olaparib & $\begin{array}{l}\text { PFS } \\
\text { OS }\end{array}$ \\
\hline
\end{tabular}


Table 1. Cont.

\begin{tabular}{|c|c|c|c|c|c|c|c|}
\hline NCT & Phase & $\begin{array}{c}\text { Experimental } \\
\text { Agent }\end{array}$ & Tumor & Setting & $N$ & Arm(s) & $\begin{array}{l}\text { Primary } \\
\text { Outcome(s) }\end{array}$ \\
\hline \multicolumn{8}{|c|}{ ATR Inhibitor } \\
\hline NCT03334617 & II & AZD6738 & NSCLC & $\geq 2$ nd line & 340 & Durvalumab + AZD6738 & ORR \\
\hline NCT03833440 & II & AZD6738 & NSCLC & 3rd - 4th line (after ICI) & 120 & Durvalumab + AZD6738 & $\begin{array}{c}\text { DCR at } 12 \\
\text { weeks }\end{array}$ \\
\hline \multicolumn{8}{|c|}{ TGFBR1 Inhibitor } \\
\hline NCT03732274 & $\mathrm{I} / \mathrm{II}$ & $\begin{array}{l}\text { Vactosertib } \\
\text { (TEW-7197) }\end{array}$ & NSCLC & After chemotherapy & 63 & Vactosertib + Durvalumab & MTD \\
\hline \multicolumn{8}{|c|}{ Epigenetic Drugs } \\
\hline NCT02437136 & $\mathrm{I} / \mathrm{II}$ & Entinostat & $\begin{array}{l}\text { NSCLC, melanoma, } \\
\text { mismatch } \\
\text { repair-proficient CRC }\end{array}$ & $\geq 2$ nd line & 202 & Entinostat + Pembrolizumab & $\begin{array}{l}\text { AEs } \\
\text { ORR }\end{array}$ \\
\hline NCT01928576 & II & Azacytidine & NSCLC & Any line & 120 & $\begin{array}{c}\text { Azacitidine + Entinostat + } \\
\text { Nivolumab }\end{array}$ & ORR \\
\hline NCT02546986 & II & Azacytidine & NSCLC & 2nd line & 100 & Pembrolizumab \pm Azacitidine & PFS \\
\hline NCT04250246 & II & Guadecitabine & $\begin{array}{l}\text { NSCLC } \\
\text { Melanoma }\end{array}$ & $\begin{array}{c}\geq 2 \mathrm{nd} \text { line } \\
\text { (only one prior line of ICIs allowed) }\end{array}$ & 184 & $\begin{array}{c}\text { Ipilimumab }+ \text { Nivolumab } \pm \\
\text { Guadecitabine }\end{array}$ & ORR \\
\hline
\end{tabular}

N: planned sample size; NCT: clinicaltrials.gov identifier; AEs: adverse events; AST: advanced solid tumors; BOR: best overall response; CPRR: complete pathological response rate; CRC: colorectal cancer; DCR: disease control rate; DLT: dose-limiting toxicities; MTD: maximum tolerated dose; NSCLC: non-small-cell lung cancer; ORR: objective response rate; OS: overall survival; PFS: progression-free survival. 
Azacytidine is a DNA-methyltransferase inhibitor and was evaluated in phase II placebo-controlled trial (NCT02546986) in combination with pembrolizumab versus pembrolizumab alone as second-line treatment in advanced NSCLC $(N=100)$ [147]. Nonetheless, no significant difference in PFS between the experimental and the control arms (2.9 versus 4.0 months, respectively) was observed. In addition, the combination arm showed the worst tolerability profile, mainly for gastrointestinal adverse events.

HDACi and bromodomain and extra-terminal (BET) inhibitors are emerging in preclinical models as target agents with the potential to increase the effectiveness of ICIs and were recently evaluated in cancer trials $[83,148]$. Birabresib (OTX015) and INCB057643 are both BET inhibitors and their safety and efficacy as monotherapy or combination with standard of care in solid tumors are currently being investigated in clinical trials, also enrolling NSCLC patients, such as NCT02259114 and NCT02711137 for OTX015 and INCB057643, respectively. The most promising of these studies is a phase I study of birabresib in advanced solid tumors that enrolled 46 patients, including 10 NSCLC patients [149]. The trial aimed to identify the best phase II dose schedule among the two tested, i.e., $80 \mathrm{mg}$ on a daily schedule and $100 \mathrm{mg}$ for 7 consecutive days every 21-day cycle. The safety profile of the selected regimen ( $80 \mathrm{mg}$ daily administered to $N=290$ patients) was manageable, and included thrombocytopenia $(N=5)$, anemia $(N=2)$, and transaminase elevation $(N=1)$ as most commonly reported grade 3 or higher toxicities.

\subsection{Targeting Growth Factors}

Among extrinsic factors affecting PD-L1 expression, TGF- $\beta 1$ has been investigated as an appealing potential target to improve immunotherapy efficacy. M7824 is a first-in-class bifunctional fusion protein, consisting of the anti-PD-L1 antibody avelumab fused with two extracellular domains made of a TGF- $\beta$ receptor (TGF- $\beta$ RII), which functions as a TGF- $\beta$ "trap" [150]. M7824 has the ability to both inhibit PD-1/PD-L1 interaction and block TGF- $\beta$ mediated mesenchymalization and tumor immune suppression, resulting in enhanced antitumor activity $[150,151]$. Safety and activity of M7824 were evaluated in a phase I trial enrolling 80 patients with advanced NSCLC patients progressing after first-line treatment [152]. Updated results of the $1200 \mathrm{mg}$ dose cohort showed an objective response rate of $27.5 \%$, with a median duration of response of 18 months and a median survival of 21.7 months in PD-L1 positive $(\geq 1 \%)$ patients, together with a manageable safety profile. A phase III trial investigating the safety and efficacy of M7824 compared to pembrolizumab as first-line treatment of advanced NSCLC patients with high PD-L1-tumor expression is currently ongoing (NCT03631706). VEGF pathway blockade results in normalization of tumor vasculature and reduced hypoxia, increasing T-cell tumor infiltration, which can establish an immune-permissive TME. According to these data, anti-VEGF treatment can act synergistically with ICIs, enhancing immune response. Preclinical data on Lewis lung carcinoma mouse models demonstrated a synergic effect by the combination of anti-PD-1 and endostar (a recombinant humanized endostatin, anti-angiogenic molecule) in suppressing tumor growth by means of improving the TME and activating PI3K/AKT/mTOR-mediated autophagy [153]. The phase III IMpower150 study randomized chemotherapy-naïve patients with advanced NSCLC to receive atezolizumab plus carboplatin plus paclitaxel (ACP group), atezolizumab plus bevacizumab plus carboplatin plus paclitaxel (ABPC group) or bevacizumab plus carboplatin plus paclitaxel (BCP) [154]. This study showed that the ABPC regimen compared to the $\mathrm{BCP}$ one provided a significant improvement in terms of ORR ( $56 \%$ vs. $40 \%$, respectively), median PFS (8.4 vs. 6.8 months, respectively), and median OS (19.8 vs. 14.9 months, respectively).

\subsection{Targeting Post-Translational Modifications}

Post-translational modifications that modulate PD-L1 expression, such as glycosylation, phosphorylation, and ubiquitination, could be potential targets for anti-cancer treatment. COP9 signalosome 5 (CSN5) is involved in TNF-a-mediated PD-L1 stabilization because of its function in deubiquitination of PD-L1 and its inhibition by curcumin may benefit immunotherapy in the reduction 
of tumor growth such as demonstrated in in vivo preclinical mouse models treated with CTLA-4 antibodies [155].

\section{Conclusions}

PD-L1 expression in NSCLC is highly variable because of the interaction of many factors, that include intrinsic (genetic, epigenetic, and post-translational factors) and extrinsic factors. The understanding of these factors may unravel potential targets to improve outcomes on ICIs in these patients, which are under investigation in clinical trials.

Author Contributions: Conceptualization: G.L. and F.G. (Francesco Gelsomino); Writing_-Original Draft Preparation: G.L., M.S., E.A. and F.G. (Francesco Gelsomino); Figures and Tables: M.S., E.A. and G.L.; Writing-Review and Editing: G.L., M.S., E.A., F.G. (Francesca Giunchi), A.P., P.-L.L., F.G. (Francesco Gelsomino) and A.A. All authors have read and agreed to the published version of the manuscript.

Funding: This research was funded by Ricerca Finalizzata Ministero della Salute 2018 grant, number GR-2018-12368031.

Conflicts of Interest: The authors declare no conflict of interest.

\section{References}

1. Mellman, I.; Coukos, G.; Dranoff, G. Cancer immunotherapy comes of age. Nature 2011, 480, 480-489. [CrossRef]

2. Larkin, J.; Chiarion-Sileni, V.; Gonzalez, R.; Grob, J.J; Cowey, C.L.; Lao, C.D.; Schadendorf, D.; Dummer, R.; Smylie, M.; Rutkowski, P.; et al. Combined Nivolumab and Ipilimumab or Monotherapy in Untreated Melanoma. N. Engl. J. Med. 2015, 373, 23-34. [CrossRef]

3. Robert, C.; Schachter, J.; Long, G.V.; Arance, A.; Grob, J.J.; Mortier, L.; Daud, A.; Carlino, M.S.; McNeil, C.; Lotem, M.; et al. Pembrolizumab versus Ipilimumab in Advanced Melanoma. N. Engl. J. Med. 2015, 372, 2521-2532. [CrossRef]

4. Reck, M.; Rodríguez-Abreu, D.; Robinson, A.G.; Hui, R.; Csőszi, T.; Fülöp, A.; Gottfried, M.; Peled, N.; Tafreshi, A.; Cuffe, S.; et al. Pembrolizumab versus Chemotherapy for PD-L1-Positive Non-Small-Cell Lung Cancer. N. Engl. J. Med. 2016, 375, 1823-1833. [CrossRef]

5. Gandhi, L.; Rodríguez-Abreu, D.; Gadgeel, S.; Esteban, E.; Felip, E.; De Angelis, F.; Domine, M.; Clingan, P.; Hochmair, M.J.; Powell, S.F.; et al. Pembrolizumab plus Chemotherapy in Metastatic Non-Small-Cell Lung Cancer. N. Engl. J. Med. 2018, 378, 2078-2092. [CrossRef] [PubMed]

6. Bellmunt, J.; de Wit, R.; Vaughn, D.J.; Fradet, Y.; Lee, J.-L.; Fong, L.; Vogelzang, N.J;; Climent, M.A.; Petrylak, D.P.; Choueiri, T.K.; et al. Pembrolizumab as Second-Line Therapy for Advanced Urothelial Carcinoma. N. Engl. J. Med. 2017, 376, 1015-1026. [CrossRef] [PubMed]

7. Powles, T.; Durán, I.; van der Heijden, M.S.; Loriot, Y.; Vogelzang, N.J.; De Giorgi, U.; Oudard, S.; Retz, M.M.; Castellano, D.; Bamias, A.; et al. Atezolizumab versus chemotherapy in patients with platinum-treated locally advanced or metastatic urothelial carcinoma (IMvigor211): A multicentre, open-label, phase 3 randomised controlled trial. Lancet 2018, 391, 748-757. [CrossRef]

8. Horn, L.; Mansfield, A.S.; Szczęsna, A.; Havel, L.; Krzakowski, M.; Hochmair, M.J.; Huemer, F.; Losonczy, G.; Johnson, M.L.; Nishio, M.; et al. First-Line Atezolizumab plus Chemotherapy in Extensive-Stage Small-Cell Lung Cancer. N. Engl. J. Med. 2018, 379, 2220-2229. [CrossRef]

9. Paz-Ares, L.; Dvorkin, M.; Chen, Y.; Reinmuth, N.; Hotta, K.; Trukhin, D.; Statsenko, G.; Hochmair, M.J.; Özgüroğlu, M.; Ji, J.H.; et al. Durvalumab plus platinum-etoposide versus platinum-etoposide in first-line treatment of extensive-stage small-cell lung cancer (CASPIAN): A randomised, controlled, open-label, phase 3 trial. Lancet 2019. [CrossRef]

10. Brahmer, J.; Reckamp, K.L.; Baas, P.; Crinò, L.; Eberhardt, W.E.E.; Poddubskaya, E.; Antonia, S.; Pluzanski, A.; Vokes, E.E.; Holgado, E.; et al. Nivolumab versus Docetaxel in Advanced Squamous-Cell Non-Small-Cell Lung Cancer. N. Engl. J. Med. 2015, 373, 123-135. [CrossRef]

11. Borghaei, H.; Paz-Ares, L.; Horn, L.; Spigel, D.R.; Steins, M.; Ready, N.E.; Chow, L.Q.; Vokes, E.E.; Felip, E.; Holgado, E.; et al. Nivolumab versus docetaxel in advanced nonsquamous non-small-cell lung cancer. N. Engl. J. Med. 2015. [CrossRef] [PubMed] 
12. Herbst, R.S.; Baas, P.; Kim, D.-W.; Felip, E.; Pérez-Gracia, J.L.; Han, J.-Y.; Molina, J.; Kim, J.-H.; Arvis, C.D.; Ahn, M.-J.; et al. Pembrolizumab versus docetaxel for previously treated, PD-L1-positive, advanced non-small-cell lung cancer (KEYNOTE-010): A randomised controlled trial. Lancet 2016, 387, 1540-1550. [CrossRef]

13. Rittmeyer, A.; Barlesi, F.; Waterkamp, D.; Park, K.; Ciardiello, F.; von Pawel, J.; Gadgeel, S.M.; Hida, T.; Kowalski, D.M.; Dols, M.C.; et al. Atezolizumab versus docetaxel in patients with previously treated non-small-cell lung cancer (OAK): A phase 3, open-label, multicentre randomised controlled trial. Lancet 2017, 389, 255-265. [CrossRef]

14. Mok, T.S.K.; Wu, Y.; Kudaba, I.; Kowalski, D.M.; Cho, B.C.; Turna, H.Z.; Castro, G.; Srimuninnimit, V.; Laktionov, K.K.; Bondarenko, I.; et al. Pembrolizumab versus chemotherapy for previously untreated, PD-L1-expressing, locally advanced or metastatic non-small-cell lung cancer (KEYNOTE-042): A randomised, open-label, controlled, phase 3 trial. Lancet 2019, 393, 1819-1830. [CrossRef]

15. Aguilar, E.J.; Ricciuti, B.; Gainor, J.F.; Kehl, K.L.; Kravets, S.; Dahlberg, S.; Nishino, M.; Sholl, L.M.; Adeni, A.; Subegdjo, S.; et al. Outcomes to first-line pembrolizumab in patients with non-small-cell lung cancer and very high PD-L1 expression. Ann. Oncol. 2019. [CrossRef]

16. Lamberti, G.; Spurr, L.F.; Li, Y.; Ricciuti, B.; Recondo, G.; Umeton, R.; Nishino, M.; Sholl, L.M.; Meyerson, M.L.; Cherniack, A.D.; et al. Clinicopathological and genomic correlates of programmed cell death ligand 1 (PD-L1) expression in nonsquamous non-small-cell lung cancer. Ann. Oncol. 2020. [CrossRef]

17. Dogan, S.; Shen, R.; Ang, D.C.; Johnson, M.L.; D’Angelo, S.P.; Paik, P.K.; Brzostowski, E.B.; Riely, G.J.; Kris, M.G.; Zakowski, M.F.; et al. Molecular epidemiology of EGFR and KRAS mutations in 3026 lung adenocarcinomas: Higher susceptibility of women to smoking-related KRAS-mutant cancers. Clin. Cancer Res. 2012. [CrossRef]

18. Coelho, M.A.; de Carné Trécesson, S.; Rana, S.; Zecchin, D.; Moore, C.; Molina-Arcas, M.; East, P.; Spencer-Dene, B.; Nye, E.; Barnouin, K.; et al. Oncogenic RAS Signaling Promotes Tumor Immunoresistance by Stabilizing PD-L1 mRNA. Immunity 2017, 47, 1083-1099. [CrossRef]

19. Chen, N.; Fang, W.; Lin, Z.; Peng, P.; Wang, J.; Zhan, J.; Hong, S.; Huang, J.; Liu, L.; Sheng, J.; et al. KRAS mutation-induced upregulation of PD-L1 mediates immune escape in human lung adenocarcinoma. Cancer Immunol. Immunother. 2017. [CrossRef]

20. Sumimoto, H.; Takano, A.; Teramoto, K.; Daigo, Y. RAS-Mitogen-Activated Protein Kinase Signal Is Required for Enhanced PD-L1 Expression in Human Lung Cancers. PLoS ONE 2016, 11, e0166626. [CrossRef]

21. Minchom, A.; Thavasu, P.; Ahmad, Z.; Stewart, A.; Georgiou, A.; O’Brien, M.E.R.; Popat, S.; Bhosle, J.; Yap, T.A.; De Bono, J.; et al. A study of PD-L1 expression in KRAS mutant non-small cell lung cancer cell lines exposed to relevant targeted treatments. PLOS ONE 2017. [CrossRef] [PubMed]

22. Okita, R.; Maeda, A.; Shimizu, K.; Nojima, Y.; Saisho, S.; Nakata, M. PD-L1 overexpression is partially regulated by EGFR/HER2 signaling and associated with poor prognosis in patients with non-small-cell lung cancer. Cancer Immunol. Immunother. 2017. [CrossRef] [PubMed]

23. Sonobe, M.; Manabe, T.; Wada, H.; Tanaka, F. Mutations in the epidermal growth factor receptor gene are linked to smoking-independent, lung adenocarcinoma. Br. J. Cancer 2005. [CrossRef]

24. Sharma, S.V.; Bell, D.W.; Settleman, J.; Haber, D.A. Epidermal growth factor receptor mutations in lung cancer. Nat. Rev. Cancer 2007, 7, 169-181. [CrossRef]

25. Shi, Y.; Au, J.S.K.; Thongprasert, S.; Srinivasan, S.; Tsai, C.M.; Khoa, M.T.; Heeroma, K.; Itoh, Y.; Cornelio, G.; Yang, P.C. A prospective, molecular epidemiology study of EGFR mutations in Asian patients with advanced non-small-cell lung cancer of adenocarcinoma histology (PIONEER). J. Thorac. Oncol. 2014. [CrossRef]

26. Chen, N.; Fang, W.; Zhan, J.; Hong, S.; Tang, Y.; Kang, S.; Zhang, Y.; He, X.; Zhou, T.; Qin, T.; et al. Up-regulation of PD-L1 by EGFR Activation Mediates the Immune Escape in EGFR-driven NSCLC. J. Thorac. Oncol. 2015. [CrossRef]

27. Akbay, E.A.; Koyama, S.; Carretero, J.; Altabef, A.; Tchaicha, J.H.; Christensen, C.L.; Mikse, O.R.; Cherniack, A.D.; Beauchamp, E.M.; Pugh, T.J.; et al. Activation of the PD-1 pathway contributes to immune escape in EGFR-driven lung tumors. Cancer Discov. 2013. [CrossRef] [PubMed]

28. Lastwika, K.J.; Wilson, W.; Li, Q.K.; Norris, J.; Xu, H.; Ghazarian, S.R.; Kitagawa, H.; Kawabata, S.; Taube, J.M.; Yao, S.; et al. Control of PD-L1 Expression by Oncogenic Activation of the AKT-mTOR Pathway in Non-Small Cell Lung Cancer. Cancer Res. 2016, 76, 227-238. [CrossRef] 
29. Zhang, N.; Zeng, Y.; Du, W.; Zhu, J.; Shen, D.; Liu, Z.; Huang, J.A. The EGFR pathway is involved in the regulation of PDL1 expression via the IL-6/JAK/STAT3 signaling pathway in EGFR-mutated non-small cell lung cancer. Int. J. Oncol. 2016. [CrossRef]

30. Lin, K.; Cheng, J.; Yang, T.; Li, Y.; Zhu, B. EGFR-TKI down-regulates PD-L1 in EGFR mutant NSCLC through inhibiting NF-кB. Biochem. Biophys. Res. Commun. 2015. [CrossRef]

31. Azuma, K.; Ota, K.; Kawahara, A.; Hattori, S.; Iwama, E.; Harada, T.; Matsumoto, K.; Takayama, K.; Takamori, S.; Kage, M.; et al. Association of PD-L1 overexpression with activating EGFR mutations in surgically resected nonsmall-cell lung cancer. Ann. Oncol. 2014. [CrossRef] [PubMed]

32. Schoenfeld, A.J.; Rizvi, H.; Bandlamudi, C.; Sauter, J.L.; Travis, W.D.; Rekhtman, N.; Plodkowski, A.J.; Perez-Johnston, R.; Sawan, P.; Beras, A.; et al. Clinical and molecular correlates of PD-L1 expression in patients with lung adenocarcinomas. Ann. Oncol. 2020. [CrossRef]

33. Rangachari, D.; VanderLaan, P.A.; Shea, M.; Le, X.; Huberman, M.S.; Kobayashi, S.S.; Costa, D.B. Correlation between Classic Driver Oncogene Mutations in EGFR, ALK, or ROS1 and 22C3-PD-L1 $\geq 50 \%$ Expression in Lung Adenocarcinoma. J. Thorac. Oncol. 2017. [CrossRef] [PubMed]

34. Gainor, J.F.; Shaw, A.T.; Sequist, L.V.; Fu, X.; Azzoli, C.G.; Piotrowska, Z.; Huynh, T.G.; Zhao, L.; Fulton, L.; Schultz, K.R.; et al. EGFR Mutations and ALK Rearrangements Are Associated with Low Response Rates to PD-1 Pathway Blockade in Non-Small Cell Lung Cancer: A Retrospective Analysis. Clin. Cancer Res. 2016, 22, 4585-4593. [CrossRef] [PubMed]

35. Hastings, K.; Yu, H.A.; Wei, W.; Sanchez-Vega, F.; DeVeaux, M.; Choi, J.; Rizvi, H.; Lisberg, A.; Truini, A.; Lydon, C.A.; et al. EGFR mutation subtypes and response to immune checkpoint blockade treatment in non-small-cell lung cancer. Ann. Oncol. 2019, 30, 1311-1320. [CrossRef]

36. Song, P.; Wu, S.; Zhang, L.; Zeng, X.; Wang, J. Correlation Between PD-L1 Expression and Clinicopathologic Features in 404 Patients with Lung Adenocarcinoma. Interdiscip. Sci. Comput. Life Sci. 2019. [CrossRef]

37. Meléndez, B.; Van Campenhout, C.; Rorive, S.; Remmelink, M.; Salmon, I.; D’Haene, N. Methods of measurement for tumor mutational burden in tumor tissue. Transl. Lung Cancer Res. 2018, 7, 661. [CrossRef]

38. Biton, J.; Mansuet-Lupo, A.; Pécuchet, N.; Alifano, M.; Ouakrim, H.; Arrondeau, J.; Boudou-Rouquette, P.; Goldwasser, F.; Leroy, K.; Goc, J.; et al. TP53, STK11, and EGFR mutations predict tumor immune profile and the response to anti-PD-1 in lung adenocarcinoma. Clin. Cancer Res. 2018. [CrossRef]

39. Toki, M.I.; Mani, N.; Smithy, J.W.; Liu, Y.; Altan, M.; Wasserman, B.; Tuktamyshov, R.; Schalper, K.; Syrigos, K.N.; Rimm, D.L. Immune Marker Profiling and Programmed Death Ligand 1 Expression Across NSCLC Mutations. J. Thorac. Oncol. 2018. [CrossRef]

40. Dong, Z.Y.; Zhang, J.T.; Liu, S.Y.; Su, J.; Zhang, C.; Xie, Z.; Zhou, Q.; Tu, H.Y.; Xu, C.R.; Yan, L.X.; et al. EGFR mutation correlates with uninflamed phenotype and weak immunogenicity, causing impaired response to PD-1 blockade in non-small cell lung cancer. Oncoimmunology 2017. [CrossRef]

41. Ota, K.; Azuma, K.; Kawahara, A.; Hattori, S.; Iwama, E.; Tanizaki, J.; Harada, T.; Matsumoto, K.; Takayama, K.; Takamori, S.; et al. Induction of PD-L1 Expression by the EML4-ALK Oncoprotein and Downstream Signaling Pathways in Non-Small Cell Lung Cancer. Clin. Cancer Res. 2015, 21, 4014-4021. [CrossRef]

42. Roussel, H.; De Guillebon, E.; Biard, L.; Mandavit, M.; Gibault, L.; Fabre, E.; Antoine, M.; Hofman, P.; Beau-Faller, M.; Blons, H.; et al. Composite biomarkers defined by multiparametric immunofluorescence analysis identify ALK-positive adenocarcinoma as a potential target for immunotherapy. Oncoimmunology 2017. [CrossRef]

43. Koh, J.; Jang, J.Y.; Keam, B.; Kim, S.; Kim, M.Y.; Go, H.; Kim, T.M.; Kim, D.W.; Kim, C.W.; Jeon, Y.K.; et al. EML4-ALK enhances programmed cell death-ligand 1 expression in pulmonary adenocarcinoma via hypoxia-inducible factor (HIF)-1 $\alpha$ and STAT3. Oncoimmunology 2016. [CrossRef] [PubMed]

44. Tamborero, D.; Gonzalez-Perez, A.; Perez-Llamas, C.; Deu-Pons, J.; Kandoth, C.; Reimand, J.; Lawrence, M.S.; Getz, G.; Bader, G.D.; Ding, L.; et al. Comprehensive identification of mutational cancer driver genes across 12 tumor types. Sci. Rep. 2013. [CrossRef] [PubMed]

45. Lamberti, G.; Brighi, N.; Maggio, I.; Manuzzi, L.; Peterle, C.; Ambrosini, V.; Ricci, C.; Casadei, R.; Campana, D. The role of mTOR in neuroendocrine tumors: Future cornerstone of a winning strategy? Int. J. Mol. Sci. 2018, 19, 747. [CrossRef] [PubMed]

46. McGowan, M.; Hoven, A.S.; Lund-Iversen, M.; Solberg, S.; Helland, Å.; Hirsch, F.R.; Brustugun, O.T. PIK3CA mutations as prognostic factor in squamous cell lung carcinoma. Lung Cancer 2017. [CrossRef] 
47. Kaneda, M.M.; Messer, K.S.; Ralainirina, N.; Li, H.; Leem, C.J.; Gorjestani, S.; Woo, G.; Nguyen, A.V.; Figueiredo, C.C.; Foubert, P.; et al. PI3K $\gamma 3$ is a molecular switch that controls immune suppression. Nature 2016. [CrossRef]

48. Cao, X.; Zhao, Y.; Wang, J.; Dai, B.; Gentile, E.; Lin, J.; Pu, X.; Ji, L.; Wu, S.; Meraz, I.; et al. TUSC2 downregulates PD-L1 expression in non-small cell lung cancer (NSCLC). Oncotarget 2017. [CrossRef]

49. Dai, B.; Yan, S.; Lara-Guerra, H.; Kawashima, H.; Sakai, R.; Jayachandran, G.; Majidi, M.; Mehran, R.; Wang, J.; Bekele, B.N.; et al. Exogenous Restoration of TUSC2 Expression Induces Responsiveness to Erlotinib in Wildtype Epidermal Growth Factor Receptor (EGFR) Lung Cancer Cells through Context Specific Pathways Resulting in Enhanced Therapeutic Efficacy. PLoS ONE 2015, 10, e0123967. [CrossRef]

50. Cortez, M.A.; Ivan, C.; Valdecanas, D.; Wang, X.; Peltier, H.J.; Ye, Y.; Araujo, L.; Carbone, D.P.; Shilo, K.; Giri, D.K.; et al. PDL1 Regulation by p53 via miR-34. J. Natl. Cancer Inst. 2016. [CrossRef]

51. Dong, Z.-Y.; Zhong, W.-Z.; Zhang, X.-C.; Su, J.; Xie, Z.; Liu, S.-Y.; Tu, H.-Y.; Chen, H.-J.; Sun, Y.-L.; Zhou, Q.; et al. Potential Predictive Value of TP53 and KRAS Mutation Status for Response to PD-1 Blockade Immunotherapy in Lung Adenocarcinoma. Clin. Cancer Res. 2017, 23, 3012-3024. [CrossRef] [PubMed]

52. Cha, Y.J.; Kim, H.R.; Lee, C.Y.; Cho, B.C.; Shim, H.S. Clinicopathological and prognostic significance of programmed cell death ligand-1 expression in lung adenocarcinoma and its relationship with p53 status. Lung Cancer 2016. [CrossRef] [PubMed]

53. Yu, X.Y.; Zhang, X.W.; Wang, F.; Lin, Y.B.; Wang, W.D.; Chen, Y.Q.; Zhang, L.J.; Cai, L. Correlation and prognostic significance of PD-L1 and P53 expression in resected primary pulmonary lymphoepithelioma-like carcinoma. J. Thorac. Dis. 2018. [CrossRef] [PubMed]

54. Skoulidis, F.; Goldberg, M.E.; Greenawalt, D.M.; Hellmann, M.D.; Awad, M.M.; Gainor, J.F.; Schrock, A.B.; Hartmaier, R.J.; Trabucco, S.E.; Gay, L.; et al. STK11/LKB1 Mutations and PD-1 Inhibitor Resistance in KRAS -Mutant Lung Adenocarcinoma. Cancer Discov. 2018, 8, 822-835. [CrossRef]

55. Koyama, S.; Akbay, E.A.; Li, Y.Y.; Aref, A.R.; Skoulidis, F.; Herter-Sprie, G.S.; Buczkowski, K.A.; Liu, Y.; Awad, M.M.; Denning, W.L.; et al. STK11/LKB1 Deficiency Promotes Neutrophil Recruitment and Proinflammatory Cytokine Production to Suppress T-cell Activity in the Lung Tumor Microenvironment. Cancer Res. 2016, 76, 999-1008. [CrossRef]

56. Xu, C.; Fillmore, C.M.; Koyama, S.; Wu, H.; Zhao, Y.; Chen, Z.; Herter-Sprie, G.S.; Akbay, E.A.; Tchaicha, J.H.; Altabef, A.; et al. Loss of lkb1 and pten leads to lung squamous cell carcinoma with elevated pd-11 expression. Cancer Cell 2014. [CrossRef]

57. Best, S.A.; De Souza, D.P.; Kersbergen, A.; Policheni, A.N.; Dayalan, S.; Tull, D.; Rathi, V.; Gray, D.H.; Ritchie, M.E.; McConville, M.J.; et al. Synergy between the KEAP1/NRF2 and PI3K Pathways Drives Non-Small-Cell Lung Cancer with an Altered Immune Microenvironment. Cell Metab. 2018. [CrossRef]

58. Mouw, K.W.; Goldberg, M.S.; Konstantinopoulos, P.A.; D'Andrea, A.D. DNA damage and repair biomarkers of immunotherapy response. Cancer Discov. 2017, 7, 675-693. [CrossRef]

59. Ricciuti, B.; Recondo, G.; Spurr, L.F.; Li, Y.Y.; Lamberti, G.; Venkatraman, D.; Umeton, R.; Cherniack, A.D.; Nishino, M.; Sholl, L.M.; et al. Impact of DNA Damage Response and Repair (DDR) Gene Mutations on Efficacy of PD-(L)1 Immune Checkpoint Inhibition in Non-Small Cell Lung Cancer. Clin. Cancer Res. 2020. [CrossRef]

60. Lamberti, G.; Andrini, E.; Sisi, M.; Federico, A.D.; Ricciuti, B. Targeting DNA damage response and repair genes to enhance anticancer immunotherapy: Rationale and clinical implication. Future Oncol. 2020. [CrossRef]

61. Garcia-Diaz, A.; Shin, D.S.; Moreno, B.H.; Saco, J.; Escuin-Ordinas, H.; Rodriguez, G.A.; Zaretsky, J.M.; Sun, L.; Hugo, W.; Wang, X.; et al. Interferon Receptor Signaling Pathways Regulating PD-L1 and PD-L2 Expression. Cell Rep. 2017. [CrossRef] [PubMed]

62. Casey, S.C.; Tong, L.; Li, Y.; Do, R.; Walz, S.; Fitzgerald, K.N.; Gouw, A.M.; Baylot, V.; Gütgemann, I.; Eilers, M.; et al. MYC regulates the antitumor immune response through CD47 and PD-L1. Science 2016. [CrossRef]

63. Wang, J.; Jia, Y.; Zhao, S.; Zhang, X.; Wang, X.; Han, X.; Wang, Y.; Ma, M.; Shi, J.; Liu, L. BIN1 reverses PD-L1-mediated immune escape by inactivating the c-MYC and EGFR/MAPK signaling pathways in non-small cell lung cancer. Oncogene 2017. [CrossRef]

64. Bouillez, A.; Rajabi, H.; Jin, C.; Samur, M.; Tagde, A.; Alam, M.; Hiraki, M.; Maeda, T.; Hu, X.; Adeegbe, D.; et al. MUC1-C integrates PD-L1 induction with repression of immune effectors in non-small-cell lung cancer. Oncogene 2017. [CrossRef] 
65. Zanconato, F.; Cordenonsi, M.; Piccolo, S. YAP/TAZ at the Roots of Cancer. Cancer Cell 2016, $29,783-803$. [CrossRef]

66. van Rensburg, H.J.J.; Azad, T.; Ling, M.; Hao, Y.; Snetsinger, B.; Khanal, P.; Minassian, L.M.; Graham, C.H.; Rauh, M.J.; Yang, X. The hippo pathway component taz promotes immune evasion in human cancer through PD-L1. Cancer Res. 2018. [CrossRef]

67. Miao, J.; Hsu, P.C.; Yang, Y.L.; Xu, Z.; Dai, Y.; Wang, Y.; Chan, G.; Huang, Z.; Hu, B.; Li, H.; et al. YAP regulates PD-L1 expression in human NSCLC cells. Oncotarget 2017. [CrossRef]

68. Lee, B.S.; Park, D.I.; Lee, D.H.; Lee, J.E.; Yeo, M.; Park, Y.H.; Lim, D.S.; Choi, W.; Lee, D.H.; Yoo, G.; et al. Hippo effector YAP directly regulates the expression of PD-L1 transcripts in EGFR-TKI-resistant lung adenocarcinoma. Biochem. Biophys. Res. Commun. 2017, 491, 493-499. [CrossRef] [PubMed]

69. Feng, J.; Yang, H.; Zhang, Y.; Wei, H.; Zhu, Z.; Zhu, B.; Yang, M.; Cao, W.; Wang, L.; Wu, Z. Tumor cell-derived lactate induces TAZ-dependent upregulation of PD-L1 through GPR81 in human lung cancer cells. Oncogene 2017. [CrossRef]

70. Goodman, A.M.; Piccioni, D.; Kato, S.; Boichard, A.; Wang, H.Y.; Frampton, G.; Lippman, S.M.; Connelly, C.; Fabrizio, D.; Miller, V.; et al. Prevalence of PDL1 amplification and preliminary response to immune checkpoint blockade in solid tumors. JAMA Oncol. 2018. [CrossRef]

71. Ikeda, S.; Okamoto, T.; Okano, S.; Umemoto, Y.; Tagawa, T.; Morodomi, Y.; Kohno, M.; Shimamatsu, S.; Kitahara, H.; Suzuki, Y.; et al. PD-L1 is upregulated by simultaneous amplification of the PD-L1 and JAK2 genes in non-small cell lung cancer. J. Thorac. Oncol. 2016. [CrossRef]

72. Clavé, S.; Pijuan, L.; Casadevall, D.; Taus, Á.; Gimeno, J.; Hernández-Llodrà, S.; Rodríguez-Rivera, M.; Lorenzo, M.; Menéndez, S.; Albanell, J.; et al. CD274 (PDL1) and JAK2 genomic amplifications in pulmonary squamous-cell and adenocarcinoma patients. Histopathology 2018. [CrossRef] [PubMed]

73. Budczies, J.; Bockmayr, M.; Denkert, C.; Klauschen, F.; Gröschel, S.; Darb-Esfahani, S.; Pfarr, N.; Leichsenring, J.; Onozato, M.L.; Lennerz, J.K.; et al. Pan-cancer analysis of copy number changes in programmed death-ligand 1 (PD-L1, CD274)—Associations with gene expression, mutational load, and survival. Genes Chromosom. Cancer 2016, 55, 626-639. [CrossRef] [PubMed]

74. Ikeda, S.; Goodman, A.M.; Cohen, P.R.; Jensen, T.J.; Ellison, C.K.; Frampton, G.; Miller, V.; Patel, S.P.; Kurzrock, R. Metastatic basal cell carcinoma with amplification of PD-L1: Exceptional response to anti-PD1 therapy. NPJ Genomic Med. 2016. [CrossRef]

75. Kataoka, K.; Shiraishi, Y.; Takeda, Y.; Sakata, S.; Matsumoto, M.; Nagano, S.; Maeda, T.; Nagata, Y.; Kitanaka, A.; Mizuno, S.; et al. Aberrant PD-L1 expression through 3'-UTR disruption in multiple cancers. Nature 2016. [CrossRef]

76. Esteller, M. Epigenetics in Cancer. N. Engl. J. Med. 2008. [CrossRef]

77. Asgarova, A.; Asgarov, K.; Godet, Y.; Peixoto, P.; Nadaradjane, A.; Boyer-Guittaut, M.; Galaine, J.; Guenat, D.; Mougey, V.; Perrard, J.; et al. PD-L1 expression is regulated by both DNA methylation and NF-kB during EMT signaling in non-small cell lung carcinoma. Oncoimmunology 2018. [CrossRef] [PubMed]

78. Zhang, S.; Che, D.; Yang, F.; Chi, C.; Meng, H.; Shen, J.; Qi, L.; Liu, F.; Lv, L.; Li, Y.; et al. Tumor-associated macrophages promote tumor metastasis via the TGF- $\beta / S O X 9$ axis in non-small cell lung cancer. Oncotarget 2017. [CrossRef]

79. Wrangle, J.; Wang, W.; Koch, A.; Easwaran, H.; Mohammad, H.P.; Vendetti, F.; VanCriekinge, W.; DeMeyer, T.; Du, Z.; Parsana, P.; et al. Alterations of immune response of non-small cell lung cancer with Azacytidine. Oncotarget 2013. [CrossRef] [PubMed]

80. Lai, Q.; Wang, H.; Li, A.; Xu, Y.; Tang, L.; Chen, Q.; Zhang, C.; Gao, Y.; Song, J.; Du, Z. Decitibine improve the efficiency of anti-PD-1 therapy via activating the response to IFN/PD-L1 signal of lung cancer cells. Oncogene 2018. [CrossRef]

81. Liu, X.; Wang, Y.; Zhang, R.; Jin, T.; Qu, L.; Jin, Q.; Zheng, J.; Sun, J.; Wu, Z.; Wang, L.; et al. HDAC10 Is Positively Associated With PD-L1 Expression and Poor Prognosis in Patients With NSCLC. Front. Oncol. 2020, 10. [CrossRef]

82. West, A.C.; Mattarollo, S.R.; Shortt, J.; Cluse, L.A.; Christiansen, A.J.; Smyth, M.J.; Johnstone, R.W. An Intact Immune System Is Required for the Anticancer Activities of Histone Deacetylase Inhibitors. Cancer Res. 2013, 73, 7265-7276. [CrossRef] 
83. Briere, D.; Sudhakar, N.; Woods, D.M.; Hallin, J.; Engstrom, L.D.; Aranda, R.; Chiang, H.; Sodré, A.L.; Olson, P.; Weber, J.S.; et al. The class I/IV HDAC inhibitor mocetinostat increases tumor antigen presentation, decreases immune suppressive cell types and augments checkpoint inhibitor therapy. Cancer Immunol. Immunother. 2018. [CrossRef] [PubMed]

84. Zheng, H.; Zhao, W.; Yan, C.; Watson, C.C.; Massengill, M.; Xie, M.; Massengill, C.; Noyes, D.R.; Martinez, G.V.; Afzal, R.; et al. HDAC inhibitors enhance T-cell chemokine expression and augment response to PD-1 immunotherapy in lung adenocarcinoma. Clin. Cancer Res. 2016. [CrossRef]

85. Bartel, D.P. MicroRNAs: Target Recognition and Regulatory Functions. Cell 2009, 136, 215-233. [CrossRef]

86. Wang, N.; Zhang, T. Downregulation of microRNA-135 promotes sensitivity of non-small cell lung cancer to gefitinib by targeting TRIM16. Oncol. Res. 2018. [CrossRef] [PubMed]

87. Tang, D.; Zhao, D.; Wu, Y.; Yao, R.; Zhou, L.; Lu, L.; Gao, W.; Sun, Y. The miR-3127-5p/p-STAT3 axis up-regulates PD-L1 inducing chemoresistance in non-small-cell lung cancer. J. Cell. Mol. Med. 2018. [CrossRef]

88. Fujita, Y.; Yagishita, S.; Hagiwara, K.; Yoshioka, Y.; Kosaka, N.; Takeshita, F.; Fujiwara, T.; Tsuta, K.; Nokihara, H.; Tamura, T.; et al. The clinical relevance of the miR-197/CKS1B/STAT3-mediated PD-L1 network in chemoresistant non-small-cell lung cancer. Mol. Ther. 2015. [CrossRef]

89. Wan, J.; Ling, X.; Peng, B.; Ding, G. MiR-142-5p regulates CD4+ T cells in human non-small cell lung cancer through PD-L1 expression via the PTEN pathway. Oncol. Rep. 2018, 40, 272-282. [CrossRef]

90. Xie, W.B.; Liang, L.H.; Wu, K.G.; Wang, L.X.; He, X.; Song, C.; Wang, Y.Q.; Li, Y.H. MiR-140 Expression Regulates Cell Proliferation and Targets PD-L1 in NSCLC. Cell. Physiol. Biochem. 2018. [CrossRef]

91. Chen, L.; Gibbons, D.L.; Goswami, S.; Cortez, M.A.; Ahn, Y.H.; Byers, L.A.; Zhang, X.; Yi, X.; Dwyer, D.; Lin, W.; et al. Metastasis is regulated via microRNA-200/ZEB1 axis control of tumour cell PD-L1 expression and intratumoral immunosuppression. Nat. Commun. 2014. [CrossRef] [PubMed]

92. Halvorsen, A.R.; Sandhu, V.; Sprauten, M.; Flote, V.G.; Kure, E.H.; Brustugun, O.T.; Helland, Å. Circulating microRNAs associated with prolonged overall survival in lung cancer patients treated with nivolumab. Acta Oncol. 2018. [CrossRef] [PubMed]

93. Sharpe, A.H.; Wherry, E.J.; Ahmed, R.; Freeman, G.J. The function of programmed cell death 1 and its ligands in regulating autoimmunity and infection. Nat. Immunol. 2007, 8, 239-245. [CrossRef] [PubMed]

94. Sato, H.; Niimi, A.; Yasuhara, T.; Permata, T.B.M.; Hagiwara, Y.; Isono, M.; Nuryadi, E.; Sekine, R.; Oike, T.; Kakoti, S.; et al. DNA double-strand break repair pathway regulates PD-L1 expression in cancer cells. Nat. Commun. 2017. [CrossRef]

95. Shin, J.; Chung, J.-H.; Kim, S.H.; Lee, K.S.; Suh, K.J.; Lee, J.Y.; Kim, J.-W.; Lee, J.-O.; Kim, J.-W.; Kim, Y.-J.; et al. Effect of Platinum-Based Chemotherapy on PD-L1 Expression on Tumor Cells in Non-small Cell Lung Cancer. Cancer Res. Treat. 2019, 51, 1086-1097. [CrossRef]

96. Suda, K.; Rozeboom, L.; Rivard, C.J.; Yu, H.; Ellison, K.; Melnick, M.A.C.; Hinz, T.K.; Chan, D.; Heasley, L.E.; Politi, K.; et al. Therapy-induced E-cadherin downregulation alters expression of programmed death ligand-1 in lung cancer cells. Lung Cancer 2017. [CrossRef]

97. Zhang, X.; Zeng, Y.; Qu, Q.; Zhu, J.; Liu, Z.; Ning, W.; Zeng, H.; Zhang, N.; Du, W.; Chen, C.; et al. PD-L1 induced by IFN- $\gamma$ from tumor-associated macrophages via the JAK/STAT3 and PI3K/AKT signaling pathways promoted progression of lung cancer. Int. J. Clin. Oncol. 2017. [CrossRef] [PubMed]

98. Deng, L.; Liang, H.; Burnette, B.; Beckett, M.; Darga, T.; Weichselbaum, R.R.; Fu, Y.-X. Irradiation and anti-PD-L1 treatment synergistically promote antitumor immunity in mice. J. Clin. Investig. 2014, 124, 687-695. [CrossRef]

99. Sakai, H.; Takeda, M.; Sakai, K.; Nakamura, Y.; Ito, A.; Hayashi, H.; Tanaka, K.; Nishio, K.; Nakagawa, K. Impact of cytotoxic chemotherapy on PD-L1 expression in patients with non-small cell lung cancer negative for EGFR mutation and ALK fusion. Lung Cancer 2019. [CrossRef]

100. Lee, S.J.; Jang, B.C.; Lee, S.W.; Yang, Y.I.; Suh, S.I.; Park, Y.M.; Oh, S.; Shin, J.G.; Yao, S.; Chen, L.; et al. Interferon regulatory factor- 1 is prerequisite to the constitutive expression and IFN- $\gamma$-induced upregulation of B7-H1 (CD274). FEBS Lett. 2006. [CrossRef]

101. Montfort, A.; Colacios, C.; Levade, T.; Andrieu-Abadie, N.; Meyer, N.; Ségui, B. The TNF paradox in cancer progression and immunotherapy. Front. Immunol. 2019, 10, 1818. [CrossRef] [PubMed]

102. Liang, Y.; Tang, H.; Guo, J.; Qiu, X.; Yang, Z.; Ren, Z.; Sun, Z.; Bian, Y.; Xu, L.; Xu, H.; et al. Targeting IFN $\alpha$ to tumor by anti-PD-L1 creates feedforward antitumor responses to overcome checkpoint blockade resistance. Nat. Commun. 2018, 9, 4586. [CrossRef] [PubMed] 
103. Chen, S.; Crabill, G.A.; Pritchard, T.S.; McMiller, T.L.; Wei, P.; Pardoll, D.M.; Pan, F.; Topalian, S.L. Mechanisms regulating PD-L1 expression on tumor and immune cells. J. Immunother. Cancer 2019. [CrossRef]

104. de Kleijn, S.; Langereis, J.D.; Leentjens, J.; Kox, M.; Netea, M.G.; Koenderman, L.; Ferwerda, G.; Pickkers, P.; Hermans, P.W.M. IFN- $\gamma$-Stimulated Neutrophils Suppress Lymphocyte Proliferation through Expression of PD-L1. PLoS ONE 2013. [CrossRef] [PubMed]

105. Noguchi, T.; Ward, J.P.; Gubin, M.M.; Arthur, C.D.; Lee, S.H.; Hundal, J.; Selby, M.J.; Graziano, R.F.; Mardis, E.R.; Korman, A.J.; et al. Temporally distinct PD-L1 expression by tumor and host cells contributes to immune escape. Cancer Immunol. Res. 2017. [CrossRef] [PubMed]

106. Platanias, L.C. Mechanisms of type-I- and type-II-interferon-mediated signalling. Nat. Rev. Immunol. 2005, 5, 375-386. [CrossRef] [PubMed]

107. Grinberg-Bleyer, Y.; Ghosh, S. A Novel Link between Inflammation and Cancer. Cancer Cell 2016, 30, 829-830. [CrossRef]

108. Gao, Y.; Lu, J.; Zeng, C.; Yang, J.; Huang, B.; Zhang, N.; Li, L.; Fu, X. IL-10 suppresses IFN- $\gamma$-mediated signaling in lung adenocarcinoma. Clin. Exp. Med. 2020, 20, 449-459. [CrossRef]

109. Evanno, E.; Godet, J.; Piccirilli, N.; Guilhot, J.; Milin, S.; Gombert, J.M.; Fouchaq, B.; Roche, J. Tri-methylation of H3K79 is decreased in TGF- $\beta 1$-induced epithelial-to-mesenchymal transition in lung cancer. Clin. Epigenetics 2017. [CrossRef]

110. Li, F.; Zhu, T.; Yue, Y.; Zhu, X.; Wang, J.; Liang, L. Preliminary mechanisms of regulating PD-L1 expression in non-small cell lung cancer during the EMT process. Oncol. Rep. 2018. [CrossRef]

111. Hsu, J.-M.; Xia, W.; Hsu, Y.-H.; Chan, L.-C.; Yu, W.-H.; Cha, J.-H.; Chen, C.-T.; Liao, H.-W.; Kuo, C.-W.; Khoo, K.-H.; et al. STT3-dependent PD-L1 accumulation on cancer stem cells promotes immune evasion. Nat. Commun. 2018, 9, 1908. [CrossRef] [PubMed]

112. Cavazzoni, A.; Digiacomo, G.; Alfieri, R.; La Monica, S.; Fumarola, C.; Galetti, M.; Bonelli, M.; Cretella, D.; Barili, V.; Zecca, A.; et al. Pemetrexed enhances membrane PD-L1 expression and potentiates T cell-mediated cytotoxicity by anti-PD-L1 antibody therapy in non-small-cell lung cancer. Cancers 2020. [CrossRef] [PubMed]

113. Jiang, X.M.; Xu, Y.L.; Huang, M.Y.; Zhang, L.L.; Su, M.X.; Chen, X.; Lu, J.J. Osimertinib (AZD9291) decreases programmed death ligand-1 in EGFR-mutated non-small cell lung cancer cells. Acta Pharmacol. Sin. 2017. [CrossRef] [PubMed]

114. Jin, R.; Zhao, J.; Xia, L.; Li, Q.; Li, W.; Peng, L.; Xia, Y. Application of immune checkpoint inhibitors in EGFR-mutant non-small-cell lung cancer: From bed to bench. Ther. Adv. Med. Oncol. 2020, 12, 1758835920930333. [CrossRef]

115. Jiang, L.; Guo, F.; Liu, X.; Li, X.; Qin, Q.; Shu, P.; Li, Y.; Wang, Y. Continuous targeted kinase inhibitors treatment induces upregulation of PD-L1 in resistant NSCLC. Sci. Rep. 2019, 9, 3705. [CrossRef]

116. Voron, T.; Colussi, O.; Marcheteau, E.; Pernot, S.; Nizard, M.; Pointet, A.L.; Latreche, S.; Bergaya, S.; Benhamouda, N.; Tanchot, C.; et al. VEGF-A modulates expression of inhibitory checkpoints on CD8++ T cells in tumors. J. Exp. Med. 2015. [CrossRef]

117. Shen, X.; Zhang, L.; Li, J.; Li, Y.; Wang, Y.; Xu, Z.X. Recent findings in the regulation of programmed death ligand 1 expression. Front. Immunol. 2019, 10, 1337. [CrossRef]

118. Noman, M.Z.; Desantis, G.; Janji, B.; Hasmim, M.; Karray, S.; Dessen, P.; Bronte, V.; Chouaib, S. PD-L1 is a novel direct target of HIF- $1 \alpha$, and its blockade under hypoxia enhanced: MDSC-mediated T cell activation. J. Exp. Med. 2014. [CrossRef]

119. Ju, X.; Zhang, H.; Zhou, Z.; Wang, Q. Regulation of PD-L1 expression in cancer and clinical implications in immunotherapy. Am. J. Cancer Res. 2020, 10, 1.

120. Horita, H.; Law, A.; Hong, S.; Middleton, K. Identifying Regulatory Posttranslational Modifications of PD-L1: A Focus on Monoubiquitinaton. Neoplasia 2017. [CrossRef]

121. Shi, Y. Regulatory mechanisms of PD-L1 expression in cancer cells. Cancer Immunol. Immunother. 2018, 67, 1481-1489. [CrossRef] [PubMed]

122. Li, C.-W.; Lim, S.-O.; Xia, W.; Lee, H.-H.; Chan, L.-C.; Kuo, C.-W.; Khoo, K.-H.; Chang, S.-S.; Cha, J.-H.; Kim, T.; et al. Glycosylation and stabilization of programmed death ligand-1 suppresses T-cell activity. Nat. Commun. 2016, 7, 12632. [CrossRef] [PubMed]

123. Cha, J.-H.; Yang, W.-H.; Xia, W.; Wei, Y.; Chan, L.-C.; Lim, S.-O.; Li, C.-W.; Kim, T.; Chang, S.-S.; Lee, H.-H.; et al. Metformin Promotes Antitumor Immunity via Endoplasmic-Reticulum-Associated Degradation of PD-L1. Mol. Cell 2018, 71, 606-620. [CrossRef] [PubMed] 
124. Wang, Y.; Wang, H.; Yao, H.; Li, C.; Fang, J.Y.; Xu, J. Regulation of PD-L1: Emerging routes for targeting tumor immune evasion. Front. Pharmacol. 2018, 9, 536. [CrossRef]

125. Wang, Y.-N.; Lee, H.-H.; Hsu, J.L.; Yu, D.; Hung, M.-C. The impact of PD-L1 N-linked glycosylation on cancer therapy and clinical diagnosis. J. Biomed. Sci. 2020, 27, 77. [CrossRef]

126. Lee, H.-H.; Wang, Y.-N.; Xia, W.; Chen, C.-H.; Rau, K.-M.; Ye, L.; Wei, Y.; Chou, C.-K.; Wang, S.-C.; Yan, M.; et al. Removal of N-Linked Glycosylation Enhances PD-L1 Detection and Predicts Anti-PD-1/PD-L1 Therapeutic Efficacy. Cancer Cell 2019, 36, 168-178. [CrossRef]

127. Zhou, M.; Chen, F.; Chen, H. Ubiquitination involved enzymes and cancer. Med. Oncol. 2014, $31,93$. [CrossRef]

128. Sadowski, M.; Suryadinata, R.; Tan, A.R.; Roesley, S.N.A.; Sarcevic, B. Protein monoubiquitination and polyubiquitination generate structural diversity to control distinct biological processes. IUBMB Life 2012, 64, 136-142. [CrossRef]

129. Linder, M.E.; Deschenes, R.J. Palmitoylation: Policing protein stability and traffic. Nat. Rev. Mol. Cell Biol. 2007, 8, 74-84. [CrossRef]

130. Yao, H.; Lan, J.; Li, C.; Shi, H.; Brosseau, J.P.; Wang, H.; Lu, H.; Fang, C.; Zhang, Y.; Liang, L.; et al. Inhibiting PD-L1 palmitoylation enhances T-cell immune responses against tumours. Nat. Biomed. Eng. 2019. [CrossRef]

131. Vansteenkiste, J.F.; Canon, J.L.; De Braud, F.; Grossi, F.; De Pas, T.; Gray, J.E.; Su, W.C.; Felip, E.; Yoshioka, H.; Gridelli, C.; et al. Safety and Efficacy of Buparlisib (BKM120) in Patients with PI3K Pathway-Activated Non-Small Cell Lung Cancer: Results from the Phase II BASALT-1 Study. J. Thorac. Oncol. 2015. [CrossRef] [PubMed]

132. Coleman, R.L.; Fleming, G.F.; Brady, M.F.; Swisher, E.M.; Steffensen, K.D.; Friedlander, M.; Okamoto, A.; Moore, K.N.; Efrat Ben-Baruch, N.; Werner, T.L.; et al. Veliparib with first-line chemotherapy and as maintenance therapy in ovarian cancer. N. Engl. J. Med. 2019. [CrossRef] [PubMed]

133. Ray-Coquard, I.; Pautier, P.; Pignata, S.; Pérol, D.; González-Martín, A.; Berger, R.; Fujiwara, K.; Vergote, I.; Colombo, N.; Mäenpää, J.; et al. Olaparib plus bevacizumab as first-line maintenance in ovarian cancer. N. Engl. J. Med. 2019. [CrossRef] [PubMed]

134. Robson, M.; Im, S.A.; Senkus, E.; Xu, B.; Domchek, S.M.; Masuda, N.; Delaloge, S.; Li, W.; Tung, N.; Armstrong, A.; et al. Olaparib for metastatic breast cancer in patients with a germline BRCA mutation. N. Engl. J. Med. 2017. [CrossRef]

135. González-Martín, A.; Pothuri, B.; Vergote, I.; DePont Christensen, R.; Graybill, W.; Mirza, M.R.; McCormick, C.; Lorusso, D.; Hoskins, P.; Freyer, G.; et al. Niraparib in patients with newly diagnosed advanced ovarian cancer. N. Engl. J. Med. 2019. [CrossRef]

136. de Bono, J.; Ramanathan, R.K.; Mina, L.; Chugh, R.; Glaspy, J.; Rafii, S.; Kaye, S.; Sachdev, J.; Heymach, J.; Smith, D.C.; et al. Phase I, dose-escalation, two-part trial of the PARP inhibitor talazoparib in patients with advanced germline BRCA1/2 mutations and selected sporadic cancers. Cancer Discov. 2017. [CrossRef]

137. Golan, T.; Hammel, P.; Reni, M.; Van Cutsem, E.; Macarulla, T.; Hall, M.J.; Park, J.O.; Hochhauser, D.; Arnold, D.; Oh, D.Y.; et al. Maintenance olaparib for germline BRCA-mutated metastatic pancreatic cancer. N. Engl. J. Med. 2019. [CrossRef]

138. Jiao, S.; Xia, W.; Yamaguchi, H.; Wei, Y.; Chen, M.K.; Hsu, J.M.; Hsu, J.L.; Yu, W.H.; Du, Y.; Lee, H.H.; et al. PARP inhibitor upregulates PD-L1 expression and enhances cancer-associated immunosuppression. Clin. Cancer Res. 2017. [CrossRef]

139. Shen, J.; Zhao, W.; Ju, Z.; Wang, L.; Peng, Y.; Labrie, M.; Yap, T.A.; Mills, G.B.; Peng, G. PARPI triggers the STING-dependent immune response and enhances the therapeutic efficacy of immune checkpoint blockade independent of BRCANEss. Cancer Res. 2019. [CrossRef]

140. Robillard, L.; Nguyen, M.; Loehr, A.; Orsulic, S.; Kristeleit, R.S.; Lin, K.; Raponi, M.; Harding, T.C.; Simmons, A.D. Abstract 3650: Preclinical evaluation of the PARP inhibitor rucaparib in combination with PD-1 and PD-L1 inhibition in a syngeneic BRCA1 mutant ovarian cancer model. Cancer Res. 2017, 77, 3650.

141. Wang, Z.; Sun, K.; Xiao, Y.; Feng, B.; Mikule, K.; Ma, X.Y.; Feng, N.; Vellano, C.P.; Federico, L.; Marszalek, J.R.; et al. Niraparib activates interferon signaling and potentiates anti-PD-1 antibody efficacy in tumor models. Sci. Rep. 2019. [CrossRef] 
142. Yu, E.Y.; Massard, C.; Retz, M.; Tafreshi, A.; Carles Galceran, J.; Hammerer, P.; Fong, P.C.C.; Shore, N.D.; Joshua, A.; Linch, M.D.; et al. Keynote-365 cohort a: Pembrolizumab (pembro) plus olaparib in docetaxel-pretreated patients (pts) with metastatic castrate-resistant prostate cancer (mCRPC). J. Clin. Oncol. 2019. [CrossRef]

143. Karzai, F.; VanderWeele, D.; Madan, R.A.; Owens, H.; Cordes, L.M.; Hankin, A.; Couvillon, A.; Nichols, E.; Bilusic, M.; Beshiri, M.L.; et al. Activity of durvalumab plus olaparib in metastatic castration-resistant prostate cancer in men with and without DNA damage repair mutations. J. Immunother. Cancer 2018. [CrossRef]

144. Lee, J.M.; Cimino-Mathews, A.; Peer, C.J.; Zimmer, A.; Lipkowitz, S.; Annunziata, C.M.; Cao, L.; Harrell, M.I.; Swisher, E.M.; Houston, N.; et al. Safety \& clinical activity of the programmed death-ligand 1 inhibitor durvalumab in combination with Poly (ADP-Ribose) polymerase inhibitor olaparib or vascular endothelial growth factor Receptor 1-3 Inhibitor Cediranib in Women's Cancers: A dose-escalati. J. Clin. Oncol. 2017. [CrossRef]

145. Cho, J.H.; Oezkan, F.; Koenig, M.; Otterson, G.A.; Herman, J.G.; He, K. Epigenetic Therapeutics and Their Impact in Immunotherapy of Lung Cancer. Curr. Pharmacol. Rep. 2017, 3, 360-373. [CrossRef] [PubMed]

146. Ager, C.; Reilley, M.; Nicholas, C.; Bartkowiak, T.; Jaiswal, A.; Curran, M.; Albershardt, T.C.; Bajaj, A.; Archer, J.F.; Reeves, R.S.; et al. 31st Annual Meeting and Associated Programs of the Society for Immunotherapy of Cancer (SITC 2016): Part two. J. Immunother. Cancer 2016, 4, 73. [CrossRef]

147. Levy, B.P.; Giaccone, G.; Besse, B.; Felip, E.; Garassino, M.C.; Domine Gomez, M.; Garrido, P.; Piperdi, B.; Ponce-Aix, S.; Menezes, D.; et al. Randomised phase 2 study of pembrolizumab plus CC-486 versus pembrolizumab plus placebo in patients with previously treated advanced non-small cell lung cancer. Eur. J. Cancer 2019. [CrossRef]

148. Adeegbe, D.O.; Liu, Y.; Lizotte, P.H.; Kamihara, Y.; Aref, A.R.; Almonte, C.; Dries, R.; Li, Y.; Liu, S.; Wang, X.; et al. Synergistic immunostimulatory effects and therapeutic benefit of combined histone deacetylase and bromodomain inhibition in non-small cell lung cancer. Cancer Discov. 2017. [CrossRef]

149. Lewin, J.; Soria, J.C.; Stathis, A.; Delord, J.P.; Peters, S.; Awada, A.; Aftimos, P.G.; Bekradda, M.; Rezai, K.; Zeng, Z.; et al. Phase Ib trial with birabresib, a small-molecule inhibitor of bromodomain and extraterminal proteins, in patients with selected advanced solid tumors. J. Clin. Oncol. 2018, 36, 3007-3014. [CrossRef]

150. David, J.M.; Dominguez, C.; McCampbell, K.K.; Gulley, J.L.; Schlom, J.; Palena, C. A novel bifunctional anti-PD-L1/TGF- $\beta$ Trap fusion protein (M7824) efficiently reverts mesenchymalization of human lung cancer cells. Oncoimmunology 2017. [CrossRef]

151. Strauss, J.; Heery, C.R.; Schlom, J.; Madan, R.A.; Cao, L.; Kang, Z.; Lamping, E.; Marte, J.L.; Donahue, R.N.; Grenga, I.; et al. Phase I trial of M7824 (MSB0011359C), a bifunctional fusion protein targeting PD-L1 and $\mathrm{TGFb}$, in advanced solid tumors. Clin. Cancer Res. 2018. [CrossRef]

152. Cho, B.C.; Kim, T.M.; Vicente, D.; Felip, E.; Lee, D.H.; Lee, K.H.; Lin, C.-C.; Flor, M.J.; Di Nicola, M.A.; Alvarez, R.M.; et al. Two-year follow-up of bintrafusp alfa, a bifunctional fusion protein targeting TGF- $\beta$ and PD-L1, for second-line (2L) treatment of non-small cell lung cancer (NSCLC). J. Clin. Oncol. 2020, 38, 9558. [CrossRef]

153. Wu, J.; Zhao, X.; Sun, Q.; Jiang, Y.; Zhang, W.; Luo, J.; Li, Y. Synergic effect of PD-1 blockade and endostar on the PI3K/AKT/mTOR-mediated autophagy and angiogenesis in Lewis lung carcinoma mouse model. Biomed. Pharmacother. 2020. [CrossRef] [PubMed]

154. Reck, M.; Mok, T.S.K.; Nishio, M.; Jotte, R.M.; Cappuzzo, F.; Orlandi, F.; Stroyakovskiy, D.; Nogami, N.; Rodríguez-Abreu, D.; Moro-Sibilot, D.; et al. Atezolizumab plus bevacizumab and chemotherapy in non-small-cell lung cancer (IMpower150): Key subgroup analyses of patients with EGFR mutations or baseline liver metastases in a randomised, open-label phase 3 trial. Lancet Respir. Med. 2019. [CrossRef]

155. Lim, S.O.; Li, C.W.; Xia, W.; Cha, J.H.; Chan, L.C.; Wu, Y.; Chang, S.S.; Lin, W.C.; Hsu, J.M.; Hsu, Y.H.; et al. Deubiquitination and Stabilization of PD-L1 by CSN5. Cancer Cell 2016. [CrossRef] [PubMed]

Publisher's Note: MDPI stays neutral with regard to jurisdictional claims in published maps and institutional affiliations. 